\title{
Climate of the Greenland ice sheet using a high-resolution climate model - Part 2: Near-surface climate and energy balance
}

\author{
J. Ettema ${ }^{1,2}$, M. R. van den Broeke ${ }^{1}$, E. van Meijgaard ${ }^{3}$, and W. J. van de Berg ${ }^{1}$ \\ ${ }^{1}$ Institute for Marine and Atmospheric research Utrecht, Utrecht University, Utrecht, The Netherlands \\ ${ }^{2}$ Faculty of Geo-Information Science and Earth Observation (ITC), University of Twente, Enschede, The Netherlands \\ ${ }^{3}$ Royal Netherlands Meteorological Institute, De Bilt, The Netherlands
}

Received: 29 March 2010 - Published in The Cryosphere Discuss.: 21 April 2010

Revised: 15 September 2010 - Accepted: 27 September 2010 - Published: 1 December 2010

\begin{abstract}
The spatial variability of near-surface variables and surface energy balance components over the Greenland ice sheet are presented, using the output of a regional atmospheric climate model for the period 1958-2008. The model was evaluated in Part 1 of this paper.

The near-surface temperature over the ice sheet is affected by surface elevation, latitude, longitude, large-scale and small-scale advection, occurrence of summer melt and mesoscale topographical features. The atmospheric boundary layer is characterised by a strong temperature inversion, due to continuous longwave cooling of the surface. In combination with a gently sloping surface the radiative loss maintains a persistent katabatic wind. This radiative heat loss is mainly balanced by turbulent sensible heat transport towards the surface. In summer, the surface is near radiative balance, resulting in lower wind speeds. Absorption of shortwave radiation and a positive subsurface heat flux due to refreezing melt water are heat sources for surface sublimation and melt.

The strongest temperature deficits $\left(>13{ }^{\circ} \mathrm{C}\right)$ are found on the northeastern slopes, where the strongest katabatic winds $\left(>9 \mathrm{~m} \mathrm{~s}^{-1}\right)$ and lowest relative humidity $(<65 \%)$ occur. Due to strong large scale winds, clear sky (cloud cover $<0.5$ ) and a concave surface, a continuous supply of cold dry air is generated, which enhances the katabatic forcing and suppresses subsidence of potentially warmer free atmosphere air.
\end{abstract}

\section{Correspondence to:}

M. R. van den Broeke

(m.r.vandenbroeke@uu.nl)

\section{Introduction}

The Greenland ice sheet (GrIS) is the largest permanent ice and snow covered area in the Northern Hemisphere. The complex orography of the GrIS, with steep gradients along the ice margins, and its highly-elevated, smooth interior, is mainly responsible for the variety of regional climates on the ice sheet (Scorer, 1988).

Two meteorological phenomena characterise the nearsurface climate of large ice sheets: a quasi-permanent temperature deficit, which is the potential temperature difference between the atmospheric boundary layer and the free atmosphere (Van den Broeke et al., 1994), and the persistent lowlevel katabatic wind circulation (Heinemann, 1999). Due to small absorption of shortwave radiation and negative net longwave radiation, the net surface radiation balance is negative, resulting in surface cooling and a stable stratification of the atmospheric boundary layer (Hoch et al., 2007). This cooling of the near-surface air results in a shallow high air pressure system located over central Greenland, which is the primary driving mechanism for the katabatic winds. These persistent katabatic winds prevent humidity to be transported to the central part of the GrIS at low atmospheric levels (Dethloff et al., 2002).

Many observational studies have been devoted to describe the climate of the GrIS. Steffen and Box (2001) used wind and temperature measurements from 18 GC-Net (Greenland Climate Network) automatic weather stations (AWSs) to describe the surface climatology at elevations above $1000 \mathrm{~m}$. Van den Broeke et al. (2008a,b,c) focused on the surface energy balance and radiative fluxes in the ablation and percolation zone of west Greenland. Hoch et al. (2007) made year-round radiative flux observations at Summit, the highest

Published by Copernicus Publications on behalf of the European Geosciences Union. 
point on the GrIS. Earlier meteorological expeditions were mainly restricted to the ablation season (Ambach, 1977a,b; Oerlemans and Vugts, 1993; Henneken et al., 1994).

However, large uncertainties remain in the observationbased climate fields due to the poor resolution of measurements in time and/or space. Regional climate models constitute a powerful means to fill this space-time gap by determining the climate parameters for the entire ice sheet over longer periods and at high spatial resolution. Due to the high computational costs, most of the previous numerical studies of the GrIS surface climatology were restricted to one ablation season up to 25 years (Cassano et al., 2001; Dethloff et al., 2002; Fettweis, 2007; Hines and Bromwich, 2008).

In this paper, we present a 51-year climatology of the nearsurface parameters wind, temperature, humidity, radiative fluxes and surface energy balance (SEB) components of the GrIS at $11 \mathrm{~km}$ resolution, from the regional climate model RACMO2/GR (Van Meijgaard et al., 2008). Only the spatial distribution of the seasonal and annual mean fields are presented for a better understanding of the main meteorological phenomena. A discussion of the modelled extreme values and temporal variability of the ice sheet climate parameters is beyond the scope of this paper, and will be discussed elsewhere. In Sect. 2, a brief description of the model and calculation methods for data analysis are given. In Sect. 3, the model climatology is presented and discussed. Concluding remarks on the present-day climatology of Greenland are made in Sect. 4.

\section{Model description and data analysis}

RACMO2 is based on the HIgh Resolution Limited Area Model (HIRLAM, Undén et al., 2002) and the global model of the European Centrum for Medium-Range Weather Forecasts (ECMWF, updated from cycle 23r4, White, 2004). With respect to the Antarctic version of RACMO2 (Van de Berg et al., 2005), several parameterization schemes have been modified, such as the physical representation of the GrIS snow/firn/ice pack processes (penetration and refreezing of meltwater, heat capacity of the snow/firn pack, surface roughness and albedo) and the temperature that determines the liquid-solid precipitation ratio (RACMO2/GR). These adaptations have been described in more detail in (Ettema et al., 2010).

The model domain of $246 \times 312$ grid points covers the entire Greenland ice sheet and part of the surrounding oceans, including Iceland, Svalbard and some Canadian ice caps. The horizontal resolution is $0.10^{\circ} \times 0.10^{\circ}$, which corresponds to approximately $11 \mathrm{~km}$; this high resolution is essential in obtaining an accurate representation of the narrow ablation zone, the steep climate gradients on the GrIS and the areas with complicated land-ice sheet-sea contrasts. RACMO2/GR has 40 atmospheric hybrid levels in the vertical. At the lateral boundaries, RACMO2/GR is forced with atmospheric information from ERA-40 (ECMWF Re-
Analysis, 1 September 1957-31 August 2002) and ECMWF operational analyses (1 September 2002-1 January 2009). The sea surface temperature and sea ice fraction are prescribed every $6 \mathrm{~h}$.

Comparison of RACMO2/GR output data with in situ measurements on and around the GrIS showed that the model has some difficulties in simulating the very stable atmospheric conditions, because of a too active mixing scheme that leads to an overestimation of the sensible heat flux SHF. Additionally, the amount of wintertime downwelling longwave radiation is underestimated, which leads to a cold surface bias of several degrees in places where it is not compensated by the positive SHF bias. Otherwise, a good agreement is found with observations, as described in Part 1 of this paper (Ettema et al., 2010). These model shortcomings should be kept in mind when reading the remainder of this paper.

\subsection{Wind}

The wind regime on the GrIS is dominated by semipermanent katabatic winds (Steffen and Box, 2001). Katabatic winds are characterised by (a) a wind speed maximum close to the surface, and (b) a constant wind direction. A useful tool to detect this persistent circulation is the directional constancy dc defined as the ratio of the vector-averaged wind speed to the mean wind speed, usually taken at $10 \mathrm{~m}$ (Bromwich, 1989):

$\mathrm{dc}=\frac{\left(\bar{u}^{2}+\bar{v}^{2}\right)^{\frac{1}{2}}}{\overline{\left(u^{2}+v^{2}\right)^{\frac{1}{2}}}}$

where $u$ and $v$ are the horizontal components of the $10 \mathrm{~m}$ wind. A dc of zero implies that the near-surface wind direction is random; when $\mathrm{dc}$ is 1 , the wind blows continuously from one direction.

\subsection{Temperature}

The near-surface air temperature $T_{2} \mathrm{~m}$ strongly depends on elevation and maximum solar zenith angle. To remove most of the elevation dependency, we compute the virtual potential temperature $\theta$ defined as the temperature an air parcel would have if it were brought to sea level without heat exchange with its surroundings:

$\theta_{\mathrm{v}}=T_{\mathrm{v}}\left(\frac{p_{0}}{p}\right)^{\frac{R_{\mathrm{d}}}{c_{\mathrm{p}}}}=(T+0.61 q)\left(\frac{p_{0}}{p}\right)^{\frac{R_{\mathrm{d}}}{c_{\mathrm{p}}}}$

where $T$ is the air temperature, $T_{\mathrm{v}}$ the virtual air temperature, $p$ the air pressure, $p_{0}=1000 \mathrm{hPa}$ the reference pressure, $R_{\mathrm{d}}=287 \mathrm{~J} \mathrm{~kg}^{-1} \mathrm{~K}^{-1}$ the gas constant of the dry atmosphere, $c_{\mathrm{p}}=1005 \mathrm{~J} \mathrm{~kg}^{-1} \mathrm{~K}^{-1}$ the specific heat of air at constant pressure, and $q$ the specific humidity introduced to take the effect of moisture on the buoyancy of the air parcel into account. 
As the GrIS spans roughly $2600 \mathrm{~km}$ from the northernmost point at Cape Morris Jesup to the southern tip at Cape Farwell, the northern part of the ice sheet receives a considerably smaller amount of shortwave radiation than the southern regions on an annual basis. Reeh (1991) presented a linear regression of the ice sheet mean annual near-surface air temperature $T_{2} \mathrm{~m}$, Reeh expressed as a function of elevation $z$ in $\mathrm{m}$ and latitude $\phi$ in ${ }^{\circ} \mathrm{N}$, based on a study by Ohmura (1987):

$T_{2 \mathrm{~m}, \text { Reeh }}=48.83-0.007924 z-0.7512 \phi$

Fausto et al. (2009) included the dependence of the annual mean $2 \mathrm{~m}$ temperature on longitude $\lambda$ in ${ }^{\circ} \mathrm{W}$. The coefficients were optimized by fitting the parameterization function to mean temperature observations from locations on land, in the ablation and in the accumulation zone of the GrIS:

$T_{2 \mathrm{~m}, \text { Fausto }}=41.83-0.006309 z-0.7189 \phi+0.0672 \lambda$

Another key factor affecting the near-surface air temperature is the radiative cooling of the surface, mainly in winter, leading to a quasi-permanent temperature deficit. A common measure for the strength of this inversion is the temperature perturbation $\Delta_{\theta}$, which is the difference between the potential temperature of the atmospheric boundary layer and of the free troposphere extrapolated to the same height (Van den Broeke and van Lipzig, 2003). A large negative value of $\Delta_{\theta}$ indicates a strong temperature inversion in the boundary layer. To calculate $\Delta_{\theta}$, we assume a linear background potential temperature profile that fits best to the free atmosphere potential temperatures. This means that the lapse rate $\gamma_{\theta}=\partial \theta / \partial z$ of the background potential temperature $\theta_{0}(z)$ is assumed constant with height $z$ in the free atmosphere:

$\theta_{0}(z)=\theta_{0}(0)+\gamma_{\theta} z$

where $\theta_{0}(0)$ is the background potential temperature at the surface, determined from layers in the free atmosphere situated between about 425 and $570 \mathrm{hPa} . \Delta_{\theta}(z)$ is then defined as the potential temperature perturbation relative to the undisturbed background or free atmosphere by:

$\Delta_{\theta}(z)=\theta(z)-\theta_{0}(z)$

Vertical integration of $\Delta_{\theta}$ over the boundary layer provides insight in the spatial distribution of cold air accumulation:

$\hat{\theta}=\int_{0}^{h} \Delta_{\theta}(z) d z$

where the height $h$ is chosen well above the top of the temperature deficit layer to avoid having to define the height of the stable atmospheric boundary layer, which is poorly constrained under stable conditions.

\subsection{Surface energy balance}

The air temperature near the surface is strongly coupled to the surface temperature $T_{\mathrm{s}}$. When the penetration of radiation into the snowpack is neglected, $T_{\mathrm{S}}$ is fully determined by the surface energy balance (SEB), which is defined as

$$
\begin{aligned}
M & =\mathrm{SW}_{\text {net }}+\mathrm{LW}_{\text {net }}+\mathrm{LHF}+\mathrm{SHF}+G_{\mathrm{s}} \\
& =\mathrm{SW}_{\downarrow}(1-\alpha)+\mathrm{LW}_{\downarrow}-\epsilon \sigma T_{\mathrm{s}}^{4}+\mathrm{LHF}+\mathrm{SHF}+G_{\mathrm{s}}
\end{aligned}
$$

where $M$ is the melt energy, $\mathrm{SW}_{\downarrow}, \mathrm{SW}_{\uparrow}, \mathrm{LW}_{\downarrow}, \mathrm{LW}_{\uparrow}$ are the downward and upward directed fluxes of shortwave and longwave radiation, $\alpha$ is the broadband surface albedo, $\epsilon$ the surface emissivity for longwave radiation $(\epsilon=0.98$ is used in RACMO2/GR for the ice sheet), $\sigma$ the Stefan-Boltzmann constant, LHF and SHF the turbulent fluxes for latent and sensible heat, and $G_{\mathrm{s}}$ the subsurface conductive heat flux at the surface. All terms are defined as positive when directed towards the surface.

SHF and LHF depend on the temperature, wind and humidity fluctuations in the surface layer:

$$
\begin{aligned}
\mathrm{SHF} & =-\rho c_{\mathrm{p}} \overline{\left(w^{\prime} \theta^{\prime}\right)}=\rho c_{\mathrm{p}} u_{*} \theta_{*} \\
\mathrm{LHF} & =-\rho L_{\mathrm{s}} \overline{\left(w^{\prime} q^{\prime}\right)}=\rho L_{\mathrm{s}} u_{*} q_{*} \\
u_{*} & =\sqrt{\tau / \rho}
\end{aligned}
$$

where $\rho$ is the air density, $c_{\mathrm{p}}$ the heat capacity of dry air at constant pressure, $L_{\mathrm{s}}$ the latent heat of sublimation, $w^{\prime}$, $\theta^{\prime}$ and $q^{\prime}$ are the turbulent fluctuations of vertical velocity, potential temperature and specific humidity, $u_{*}, \theta_{*}$ and $q_{*}$ the associated turbulent scaling parameters, and $\tau$ the wind shear or horizontal momentum flux.

In RACMO2/GR, the SEB is iteratively solved for the surface temperature using Monin-Obukhov similarity theory for the turbulent fluxes with the stability functions proposed by Holtslag and Bruin (1988) for stable and Dyer (1974) for unstable conditions. Since $u_{*}, \theta_{*}$ and $q_{*}$ are not available in the model output, their values have been derived from annual means for the turbulent heat fluxes, to provide qualitative insight in the relative contribution of wind shear, specific humidity and temperature gradients to the turbulent heat fluxes.

\section{Surface climate}

In this section, we present the mean annual (1 January-31 December) values of the surface climate variables air pressure, temperature, wind and SEB components as simulated by RACMO2/GR averaged over the period 1958-2008.

\subsection{Large scale circulation}

Figure 1 shows the 1958-2008 annual, winter (DJF) and summer (JJA) sea-level pressure (dashed lines) and height of the $500 \mathrm{hPa}$ level $Z_{500}$ (solid lines). The mean surface level pressure is not plotted over land, because the topography of 

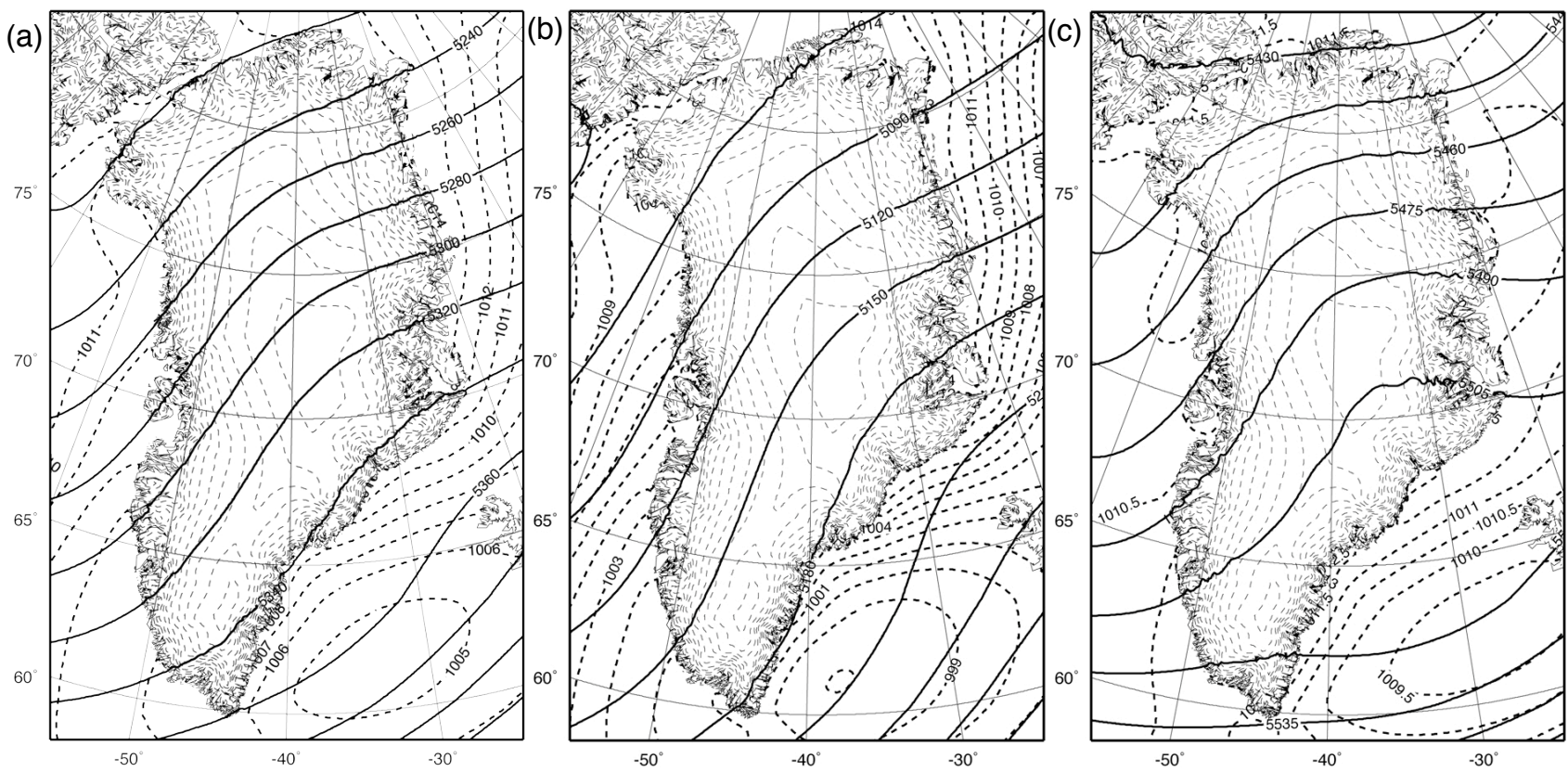

Fig. 1. Mean $500 \mathrm{hPa}$ height $Z_{500}$ [m a.s.1.; solid contours], sea level pressure $p_{\mathrm{s}}[\mathrm{hPa}$; dashed contours over ocean only], topography of the GrIS [m; dashed contours every $250 \mathrm{~m}$ over land only] averaged over (a) a year, and the seasons (b) DJF and (c) JJA. Note the differences in contour increments.

the GrIS and the strong density profiles make downward interpolation highly uncertain. The $500 \mathrm{hPa}$ level is chosen here, because it is the first standard pressure level that does not intersect with the ice sheet surface and lies well above the surface layer.

The GrIS is situated just poleward of the polar front; the strong baroclinicity results in a westerly upper air flow and an easterly near-surface flow. Because the ice sheet is also situated in the northward directed branch of the standing planetary waves in the Northern Hemisphere, the $500 \mathrm{hPa}$ circulation is directed southwest-northeast, forcing upper-air southwesterlies over the GrIS that constitute the so-called polar vortex. RACMO2/GR is well capable of realistically simulating these large scale circulation patterns (Fig. 1), as expected because of the use of lateral forcings from ECMWF analyses.

The North Atlantic main storm track is located around southern Greenland and cause relatively high accumulation rates over western and southeastern Greenland (Ohmura and Reeh, 1991; Steffen and Box, 2001; Ettema et al., 2009). The net effect of the individual low pressure systems results in a climatologic low pressure system $(1004.5 \mathrm{hPa})$ located over the Irminger Sea, the so-called Icelandic Low. The wintertime Icelandic Low is relatively deep (below $1000 \mathrm{hPa}$ ) and positioned close to the east coast of south Greenland, while in summer the low is less deep (about $1009 \mathrm{hPa}$ ) and centred close to the south coast of Iceland. Position and depth of the Icelandic Low is well represented in RACMO2/GR.
With elevations over $3000 \mathrm{~m}$, the GrIS acts as a barrier for weather systems in the North Atlantic region. It prevents cyclones to move directly from west to east across the ice sheet. Rather, the main pathways are northward along the western flank or eastward south of the GrIS, and retrogade eastwards at higher latitudes (Scorer, 1988). Locally, the steep topographic gradients in southeast Greenland have a pronounced effect on the synoptic systems, for example, by splitting low air pressure systems at the southern tip of Greenland, by distorting the wind and temperature fields and by inducing cyclogenesis on the lee-side of the steep slopes in the south (Tsukernik et al., 2007).

\subsection{Near-surface wind}

Over the GrIS, the annual mean $10 \mathrm{~m}$ wind speeds (19582008 average) range from 1.5 to $10.3 \mathrm{~m} \mathrm{~s}^{-1}$ (Fig. 2a). The lowest mean annual wind speeds are found over the tundra and adjacent ice sheet along the northern and western margins. The reduced wind speed at $10-20 \mathrm{~km}$ from the ice edge is confirmed by AWS observations (Duynkerke and van den Broeke, 1994; Van den Broeke et al., 2008c). This deceleration of the katabatic flow is partly caused by increasing surface roughness lengths due to a rougher ice surface in the ablation zone, but also by the diurnal variation in the thermally forced wind imposed by the flat tundra close to the ice edge. This thermal wind forcing is associated with cold air pooling over the tundra (Van den Broeke et al., 1994, 2002; Gallée and Pettré, 1998). The cold, stagnant air builds up in 
(a)

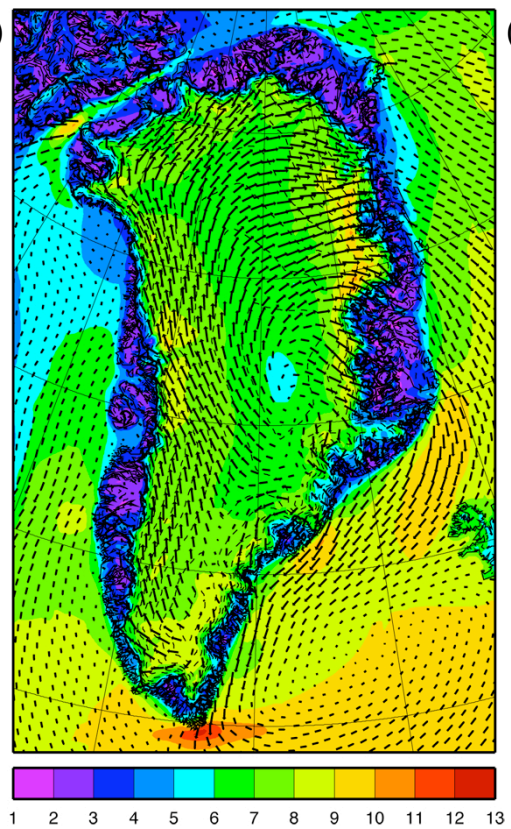

(b)

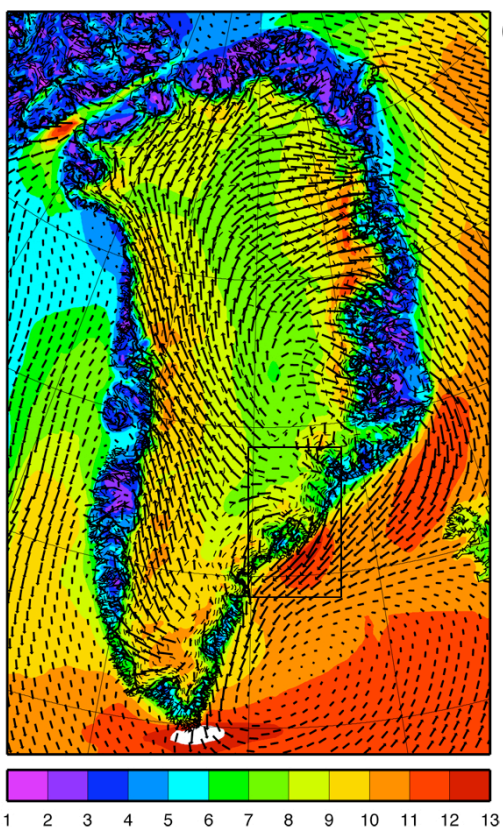

(c)

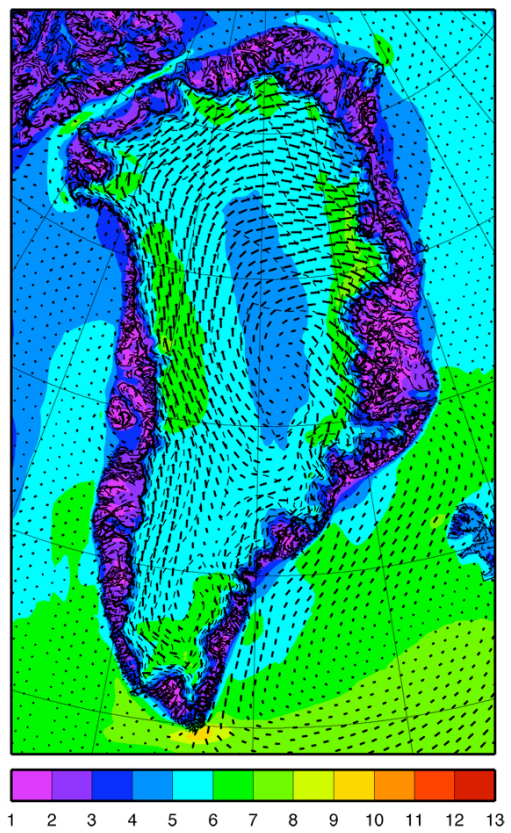

Fig. 2. Averaged $10 \mathrm{~m}$ wind speed (contours, $\left[\mathrm{m} \mathrm{s}^{-1}\right]$ ) and wind vectors over (a) a year, the seasons (b) DJF and (c) JJA. Vectors are plotted every 4 grid points for clarity. Box in (b) indicates region enlarged in Fig. 3 b.

all months except summer, inhibiting exchange with the free atmosphere. Moreover, the lower wind speed over the tundra can be explained by the strength of the temperature inversion and the disintegration of the katabatic wind system over the inhomogeneous tundra surface.

The highest simulated wind speeds on the ice sheet occur in northeast Greenland over Dronning Louise Land and to its south. Unfortunately, no direct meteorological observations are available for this region. The AWS locations NASA$\mathrm{E}$ and Tunu-N from GC-Net are located higher up the ice sheet (Steffen and Box, 2001). Wind speeds in winter (DJF, Fig. 2b) are generally larger than in summer (JJA, Fig. 2c). In winter, cloud cover is low and there is enhanced radiative surface cooling, as discussed in Sect. 3.5, leading to stronger katabatic forcing. Furthermore, the polar vortex is stronger in winter, as it is proportional to the large-scale temperature gradient between the North Pole and the equator, which is largest in wintertime. As in Antarctica, the large scale pressure gradient force (PGF) acts to support the katabatic PGF over the ice sheet in the northeast (Van den Broeke et al., 2002).

The mean wind vectors show a clear outflow of air over the ice sheet surface. The mean wind direction is a downslope with a deflection to the right due to the Coriolis force, giving rise to an anti-cyclonic pattern. Assuming a continuous katabatic forcing and steady state without friction, the flow would be along the elevation contours close at the surface. Friction maintains a downslope component, but apparently, the west coast of Greenland is strongly influenced by the low pressure systems in the northern Baffin Bay, resulting in a flow (a)
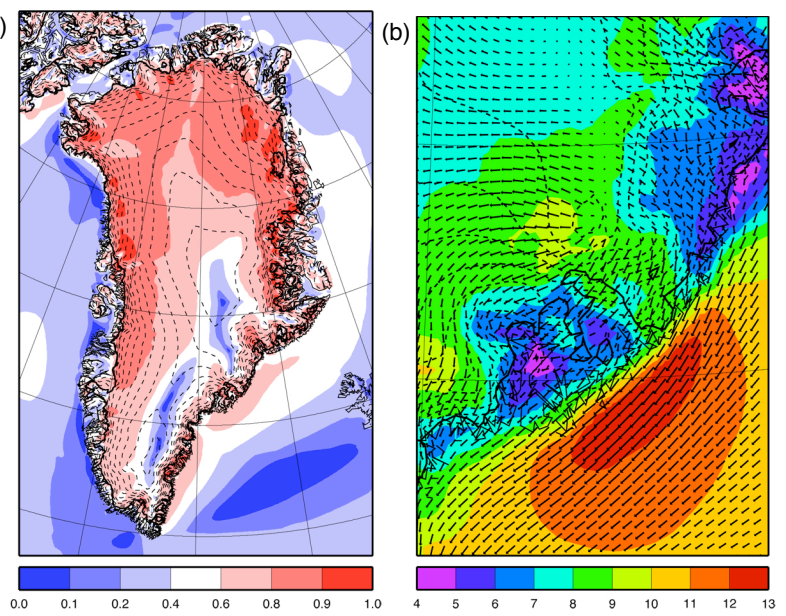

Fig. 3. (a) Directional constancy [-] based on annual wind speed and direction, and (b) DJF mean of $10 \mathrm{~m}$ wind field (vectors $\left[\mathrm{m} \mathrm{s}^{-1}\right]$ ) and its magnitude (colouring $\left[\mathrm{m} \mathrm{s}^{-1}\right]$ ) plotted at full model resolution for the box indicated in Fig. 2 b.

almost parallel to the elevation contours. Along the $2000 \mathrm{~m}$ contour, the modelled wind direction corresponds well to the observations of Steffen and Box (2001).

The katabatic winds over the ice sheet are persistent throughout the year, which is reflected in a high mean value of $\mathrm{dc}(\approx 0.6)$ for most of the GrIS (Fig. 3a). The largest values of dc $(>0.9)$ coincide with areas of strong katabatic winds. The katabatic wind system dissipates after crossing the ice edge, resulting in low wind speeds and low values for $\mathrm{dc}$ 
over the tundra. On the ice sheet, the lowest values for dc are found on the two domes and the ridge in between. Here, the wind direction is governed by the large scale circulation, since the katabatic wind system is weakly developed in these areas in the absence of a significant surface slope.

The $10 \mathrm{~m}$ wind direction over the adjacent oceans is highly variable. Throughout the year, a clear maximum of the annual mean wind speed $\left(<14 \mathrm{~m} \mathrm{~s}^{-1}\right)$ is located south of the southernmost tip of Greenland with a rather low value for $\mathrm{dc}$ of 0.3 . Here, the steep and high topography of the GrIS results in significant atmospheric flow distortion that leads to a common occurrence of high surface wind speeds in its surrounding area, the so-called Greenland tip jet (Moore and Renfrew, 2005). The low dc can be explained by the bimodality of the zonal wind in this area, with high wind speed events occurring from both directions.

The regional high wind speeds along the southeastern coast at $\sim 66^{\circ} \mathrm{N}$ are more persistent throughout the year. Figure $2 \mathrm{~b}$ shows that the cold and stably stratified katabatic outflow through the numerous fjords is forced back towards the topographic barrier by the prevailing synoptic-scale easterly flow. This so-called barrier wind is seen in more detail when zooming in on this region and plotting the DJF averaged wind vectors at the full model resolution of $11 \mathrm{~km}$ (Fig. 3b). Moore and Renfrew (2005) observed these barrier winds in the near-surface wind speed fields derived from QuickScat data. It confirms the ability of RACMO2/GR to simulate the regional wind climate accurately, not only on the ice sheet, but also over the surrounding oceans, which is beneficial for the forcing of regional ocean models.

\subsection{Near-surface temperature}

Figure 4 shows the mean annual, winter and summer $2 \mathrm{~m}$ temperature and sea ice extent (shaded) where the ocean is ice-covered for more than $75 \%$ of the time (average 19582008). The sea ice cover is generally most extensive in spring and could lead to a time lag in temperature minimum in some coast areas (Scorer, 1988). The annual mean air temperature over the GrIS ranges from -30.5 to $-3.5^{\circ} \mathrm{C}$. The lowest temperatures are found north of the highest elevations of the GrIS, which is in agreement with the findings of Chen et al. (1997) and Cassano et al. (2001). The climate at the eastern side of Greenland is colder compared to the western side at the same altitude and latitude. This agrees with the findings of Steffen and Box (2001) and Fausto et al. (2009). A possible cause could be the insulating effect of the sea ice present along the north and northeastern coastline of Greenland and the advection of cold air by downslope winds.

During wintertime, the absence of sunlight and the presence of sea ice result in very low air temperatures in the northern regions (Fig. 4b). In summer, the melting snow/ice at the surface constrains the air temperature to close to the melting point along the ice margins (Fig. 4c). The highly elevated interior shows the largest annual cycle in daily mean
$T_{2 \mathrm{~m}}$. Here, the daily winter temperature can drop below $-70^{\circ} \mathrm{C}$, while in summer the temperature rises close to the melting point. The lowest variability is found along the lower margins in the southeast, where the temperature is governed by advection of warm and humid (cloudy) air throughout the year. Because everywhere on the GrIS, the mean temperature for the warmest month is below $10^{\circ} \mathrm{C}$, the climate of the GrIS can be classified as Arctic. Only where the land strip is wider than $100 \mathrm{~km}$ and becomes snow free in summer does the July temperature rise above this threshold. These northeastern and western tundras have a subarctic climate.

The near-surface temperature is evidently affected by surface elevation, latitude and sea ice extent. Figure 5a shows that the influence of the surface elevation can be largely removed by considering the $2 \mathrm{~m}$ potential temperature $\theta_{2} \mathrm{~m}$ (Eq. 2). The southern dome at the GrIS experiences the highest $\theta_{2} \mathrm{~m}$, which generally decreases with latitude. The high $\theta_{2 \mathrm{~m}}$ values over the southern and southeastern GrIS signify frequent advection of warm maritime air and a weak temperature inversion. The low values over the northern tundra are caused by the absence of katabatic wind and warm air advection, enabling a strong inversion to build up. Over the adjacent oceans, $\theta_{2 \mathrm{~m}}$ is clearly affected by the presence of sea ice, insulating the warm ocean from the atmosphere.

Figure $5 \mathrm{~b}$ shows the difference between annual mean $T_{2 \mathrm{~m}, \text { Reeh }}$ as computed with Eq. (3) and $T_{2 \mathrm{~m}}$ simulated by RACMO2/GR. This comparison confirms that elevation and latitude are of major influence on the near-surface temperature, but can not entirely explain the temperature distribution in Fig. 4a. The difference ranges from $-5^{\circ} \mathrm{C}$ in the eastern regions to $+6^{\circ} \mathrm{C}$ close to the northern ice margins. The empirical function generally underestimates $T_{2} \mathrm{~m}$ by 1 to $3^{\circ} \mathrm{C}$. Positive biases occur only along the lowest ice sheet margins $(<750 \mathrm{~m})$. The GrIS averaged bias of $-1.4{ }^{\circ} \mathrm{C}$ implies that other processes affect the near-surface temperature as well.

Using a different set of optimal coefficients and including the temperature dependence on longitude according to Fausto et al. (2009) (Eq. 4) changes the sign of the bias, which is reduced to $+0.7^{\circ} \mathrm{C}$. Figure $5 \mathrm{c}$ shows that for this function the absolute bias is less than $1^{\circ} \mathrm{C}$ for most of the ice sheet. Including the longitudinal dependency could not remove the large positive biases along the eastern margins. Neglecting the recent warming since the 1990s (Hanna et al., 2008) and considering the model output for the period 1958 1990 only, the bias with Reeh (1991) decreases to $-1.2^{\circ} \mathrm{C}$ averaged over the ice sheet. For Fausto et al. (2009), the bias slightly increased to $0.9^{\circ} \mathrm{C}$, due to the fact that this parameterization is optimized for the period 1996-2006. All in all, the agreement is quite good, given the simplicity of these empirical relations.

\subsubsection{Potential temperature deficit $\Delta_{\theta}$}

Figure 6a shows the annual background surface potential temperature $\theta_{0}(0)$ (Eq. 5). $\theta_{0}(0)$ is generally higher than 
(a)

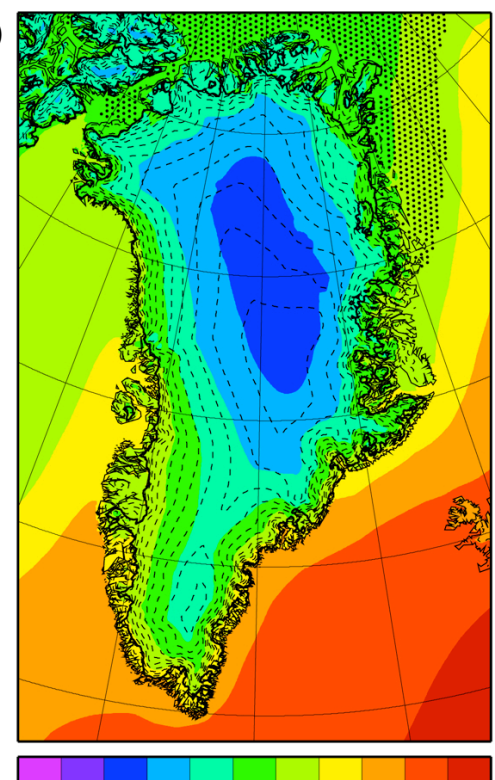

$230 \quad 235240245250255260 \quad 265 \quad 270 \quad 275 \quad 280 \quad 285$ (b)

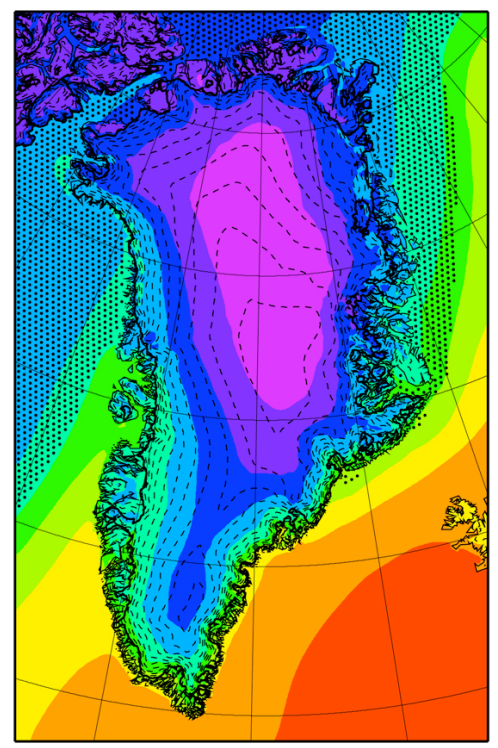

$230 \quad 235240245250255260265 \quad 270 \quad 275 \quad 280 \quad 285$ (c)

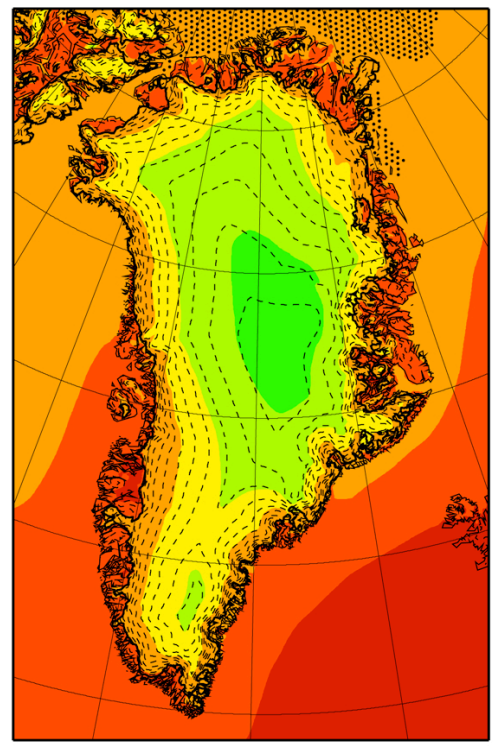

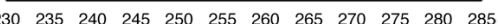

Fig. 4. Averaged $2 \mathrm{~m}$ temperature (colour contours, $[\mathrm{K}]$ ) and sea ice extent (shaded) over (a) a year, and the seasons (b) DJF and (c) JJA.

(a)

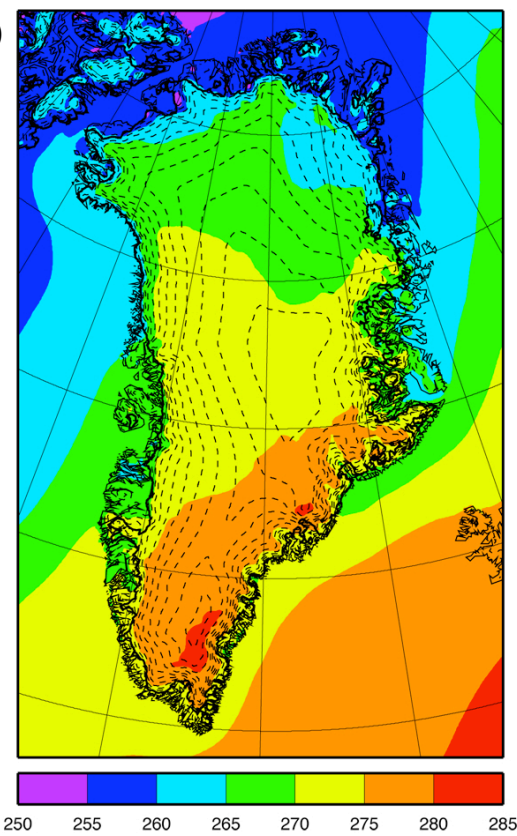

(b)

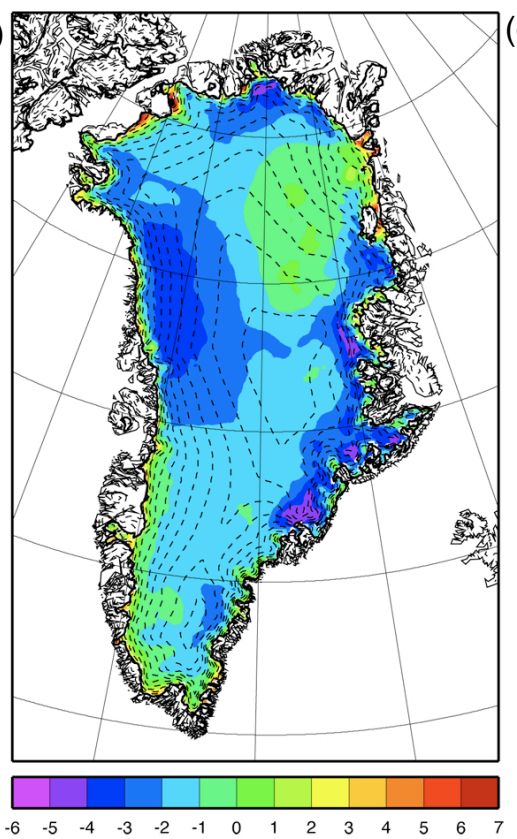

(c)

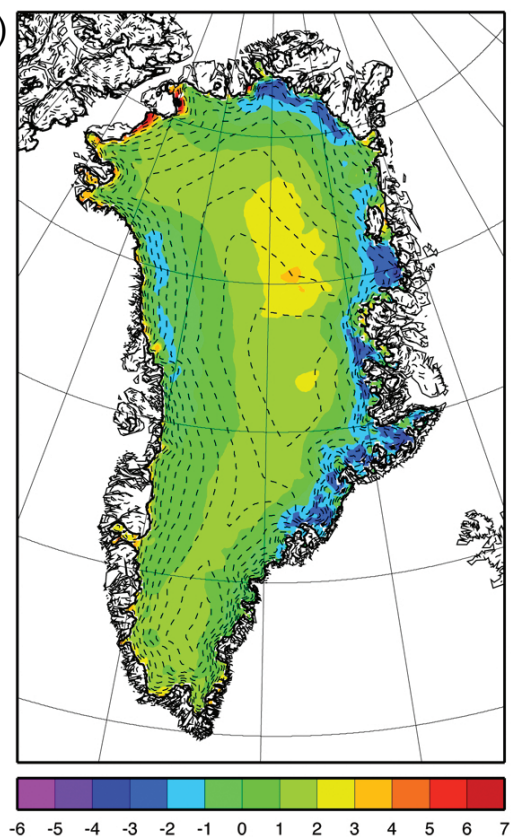

Fig. 5. (a) Annual mean $2 \mathrm{~m}$ potential temperature [K], and (b) difference between $T_{2} \mathrm{~m}$, Reeh computed with Eq. (3) Reeh (1991) and mean annual $2 \mathrm{~m}$ temperature of RACMO2/GR [ ${ }^{\circ} \mathrm{C}$ ], and (c) difference between $T_{2} \mathrm{~m}$ computed according to (Fausto et al., 2009) and mean annual $2 \mathrm{~m}$ temperature of $\mathrm{RACMO} 2 / \mathrm{GR}\left[{ }^{\circ} \mathrm{C}\right]$.

the actual surface potential temperature, $\theta(0)$, implying that the free atmosphere is potentially warmer than the boundary layer. A clear northwest-southeast gradient is seen over the ocean, which corresponds with the spatial variability in the geopotential height at the $500 \mathrm{hPa}$ level (Fig. 1). The highest values of $\theta_{0}(0)$ are found over the higher elevations of the
GrIS, indicative of the stable stratification of the free atmosphere $\left(\gamma_{\theta}>0\right.$, Fig. $\left.6 \mathrm{~d}\right)$. The free atmosphere is less stably stratified over the convective area in the surroundings of the Icelandic Low.

The annual potential temperature perturbation at the surface $\Delta_{\theta}(0)$ is depicted in Fig. 6b. A strong temperature 
(a)

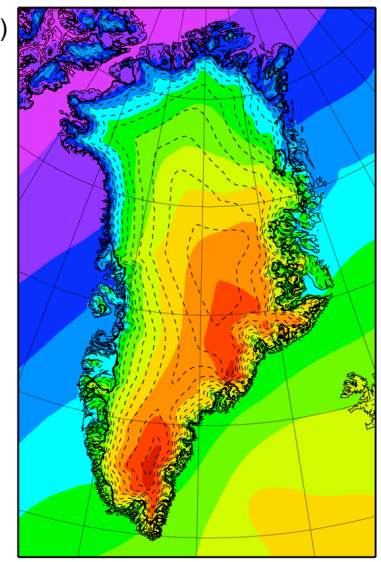

268270272274276278280282284286288290292

(c)

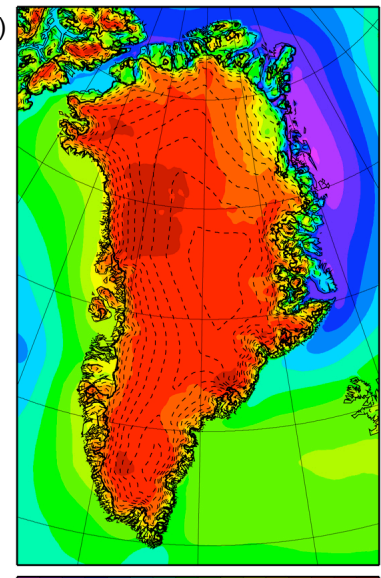

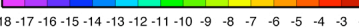
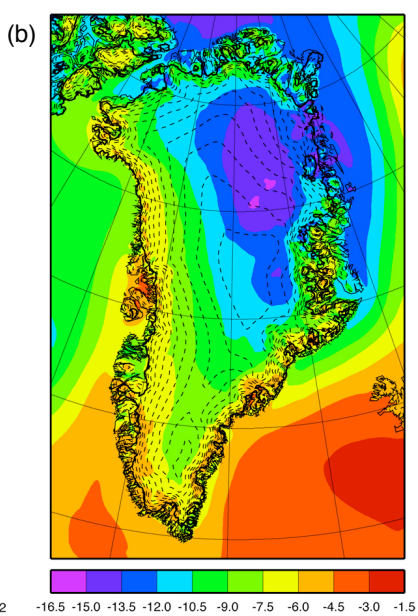

(d)

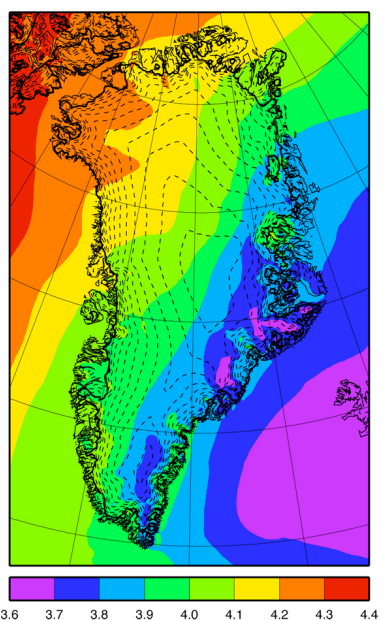

Fig. 6. Annual mean (a) background surface potential temperature $[\mathrm{K}]$, (b) surface potential temperature perturbation $[\mathrm{K}]$, (c) vertically integrated potential temperature perturbation $\left[10^{3} \mathrm{~K} \mathrm{~m}\right]$, and (d) lapse rate of the background potential temperature $\left[\mathrm{K} \mathrm{km}^{-1}\right]$.

deficit $\left(>10^{\circ} \mathrm{C}\right)$ is restricted to the northeastern part of the ice sheet and the sea ice covered areas with smaller values on the southern and western lower ice margins, and over the open ocean. Over the GrIS, a dependency of the temperature deficit on the topography, cloud cover (see later) and the presence of nearby sea ice is visible. The strongest temperature perturbations (more than $13^{\circ} \mathrm{C}$ ) are found on the northeastern slopes, also where the strongest katabatic winds occur. We speculate that southeasterly large scale winds (Fig. 1) force a continuous supply of cold air from the higher elevated parts of the ice sheet to this area. Moreover, the ice sheet surface topography forces a regional convergence of the winds in this area, prohibiting the boundary layer to heat up by divergence and associated subsidence. The result is that the air remains cold and katabatic winds strong. In comparison to the Antarctic plateau (Van de Berg et al., 2008), we find considerably smaller values for the temperature deficit on the GrIS, because Greenland experiences a regular large scale

(a)

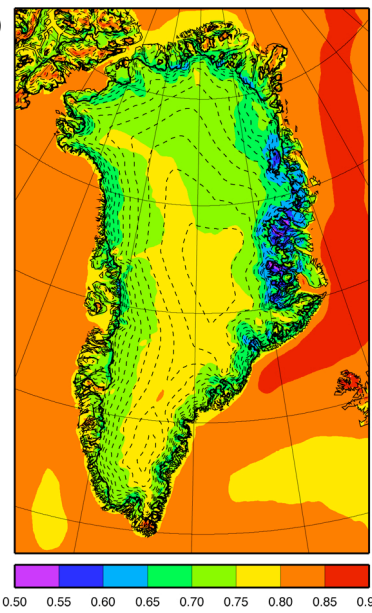

(b)

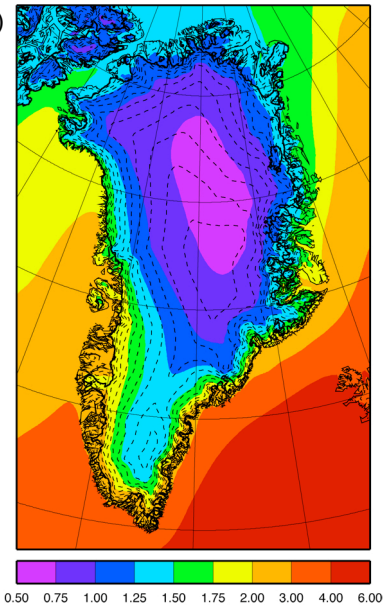

Fig. 7. Annual mean $2 \mathrm{~m}$ (a) relative humidity [-], and (b) specific humidity $\left[\mathrm{g} \mathrm{kg}^{-1}\right]$.

advection of warm air from the sea ice free Atlantic Ocean and is in general situated in a more temperate climate zone.

Figure $6 \mathrm{c}$ shows the vertically integrated temperature perturbation $\hat{\theta}$ (Eq. 7). The greatest magnitudes are found just seaward of the northeastern Greenland coastline, where the ocean is covered by sea ice for 50 to $95 \%$ of the year. This flat area acts as a collector of cold air that drains from the GrIS. The values over the ice sheet become more negative towards the margins, suggesting that in the interior the katabatic outflow of cold air over the surface is compensated by a continuous subsidence of warmer air from the free atmosphere, diminishing the vertical extent of the temperature deficit layer and, hence, of $\hat{\theta}$.

\subsection{Near-surface humidity}

Figure 7 shows that the annual mean $2 \mathrm{~m}$ relative humidity $\mathrm{RH}_{2 \mathrm{~m}}$ (average 1958-2008) decreases towards the ice margins, while the $2 \mathrm{~m}$ specific humidity $q_{2} \mathrm{~m}$ increases. $\mathrm{RH}_{2 \mathrm{~m}}$ is lowest in glacial valleys in the northeast. The strong katabatic winds advect cold, dry air from the ice sheet interior and meanwhile the katabatic system prevents humidity transport towards the northeast. In summer, the air warms the tundra and consequently $\mathrm{RH}_{2 \mathrm{~m}}$ is reduced. In contrast, $q_{2 \mathrm{~m}}$ increases, because the higher temperatures allow an exponentially higher maximum moisture content, dominating the decrease in $\mathrm{RH}_{2 \mathrm{~m}}$. Due to the strong correlation between temperature and specific humidity, the spatial pattern of $q_{2 \mathrm{~m}}$ is very similar to the distribution of $T_{2 \mathrm{~m}}$ (Fig. 4a), with the lowest values in the cold interior and the warmer air containing more moisture along the southern ice margins.

\subsection{Surface energy balance}

The surface energy balance (SEB) determines the surface temperature and melt (Eq. 8). The radiative fluxes contribute 

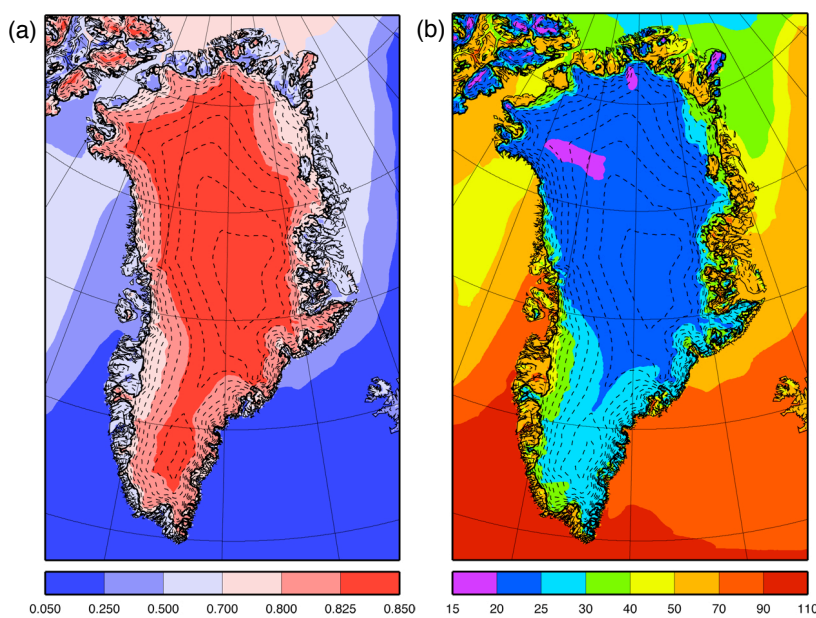

Fig. 8. Annual mean (a) surface albedo [-], and (b) net solar radiation $\left[\mathrm{W} \mathrm{m}^{-2}\right]$.

importantly to the ice sheet SEB, whereas the turbulent heat fluxes are expected to be smaller than in mid-latitude climates. Observations show that net shortwave radiation provides a significant part of the energy used for melt in the ablation zone, in spite of the relatively high surface albedo (e.g. Duynkerke and van den Broeke, 1994; Konzelmann and Braithwaite, 1995 and Van den Broeke et al., 2008b). The subsurface heat flux $G_{\mathrm{s}}$ is expected to play a minor role in the annual mean SEB. If the sum of all terms at the righthand side in Eq. (8) is positive, the remaining energy is used for melting the surface snow/ice, $M$.

\subsubsection{Net surface solar radiation and surface albedo}

The snow surface of the GrIS has a high albedo $\alpha$ and, hence, reflects the incoming shortwave radiation $\mathrm{SW}_{\downarrow}$ effectively. Over central Greenland, the annual mean modelled $\alpha$ is about 0.825 , which corresponds with the albedo of fresh snow (Fig. 8a). Consequently, the largest part of $\mathrm{SW}_{\downarrow}$ is reflected and the fraction absorbed at the annual surface $\mathrm{SW}_{\text {net }}$ reaches values between 20 and $25 \mathrm{~W} \mathrm{~m}^{-2}$ (Fig. 8b). These values correspond well to the observed mean values for albedo (0.82) and net shortwave radiation $\left(24 \mathrm{~W} \mathrm{~m}^{-2}\right)$ at Summit averaged over the period July 2000-July 2002 (Hoch, 2005).

The albedo decreases towards the ice margins due to larger snow grains during spring and summer melt periods. In the percolation zone, the decrease in $\alpha(\alpha \sim 0.7)$ is also associated with the moistening of the snow pack, while in the ablation zone, in addition, the relatively dark glacier ice $(\alpha \sim 0.5)$ appears at the surface during a few days up to weeks or even months per year. Due to the lower albedo, $\mathrm{SW}_{\text {net }}$ increases to almost $50 \mathrm{~W} \mathrm{~m}^{-2}$ along the ice margins on an annual basis and to $125 \mathrm{~W} \mathrm{~m}^{-2}$ if averaged over the summer (JJA). On the adjacent tundra, the annual and summer mean values are (a)

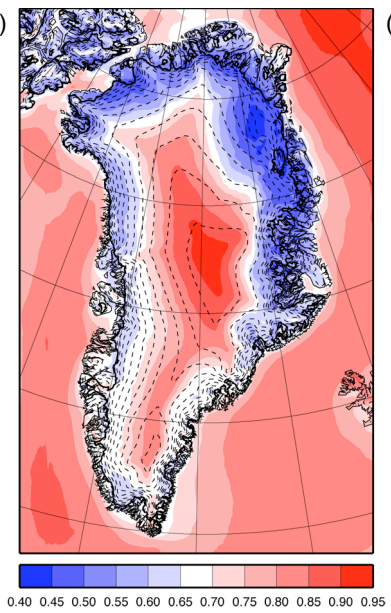

(b)

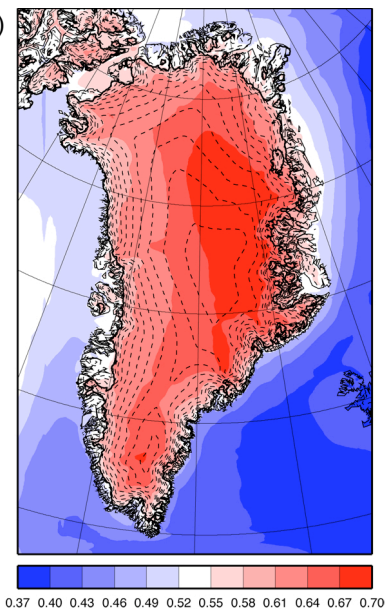

Fig. 9. Annual mean (a) total cloud cover [-], and (b) atmospheric $\mathrm{SW}$ transmissivity $\left(\mathrm{SW}_{\downarrow} / \mathrm{SW}_{\downarrow}, \mathrm{TOA}\right)[-]$.

even higher ( $\sim 70$ and $160 \mathrm{~W} \mathrm{~m}^{-2}$, respectively) due to the low summer albedo $(\alpha \sim 0.18)$ of the snow free tundra.

\subsubsection{Cloud cover and longwave radiation}

Information about clouds is valuable for a correct interpretation of the temporal and spatial variability of the radiative fluxes. Figure 9a shows that the annual mean total cloud cover decreases sharply from the interior ice sheet $(>0.9)$ towards the ice margin, with the lowest values of 0.45 found in the northeast. The high amount of cloud cover in the interior often only consists of a shallow near-surface fog layer, as has been confirmed by observations at Summit during summer nights (Hoch et al., 2007). However, the effect of clouds on radiation is primarily determined by the presence of liquid water and ice in the atmosphere. Total cloud cover does not provide quantitative information on radiative scattering properties of the atmosphere, because it is not a good measure for the optical thickness of the cloud. Therefore, we analysed the atmospheric SW transmissivity, defined as the ratio between the incoming SW at the surface and at the top of the atmosphere, which depends on the amount and vertical distribution of water vapour, clouds, atmospheric mass and aerosols.

Figure 9b shows that SW transmissivity reveals a different spatial pattern than cloud cover. It increases with elevation, caused by a shorter associated atmospheric pathway for shortwave radiation. The low cloud cover in northeast Greenland coincides with relatively high values in SW transmissivity, indicative for dry air advected by the strong katabatic winds. Note that Summit, besides having the highest mean cloud cover, still has very high transmissivity. This confirms that the simulated cloud layer is very thin or only occurs at low sun angles, which is typical for radiative fog. 
(a)

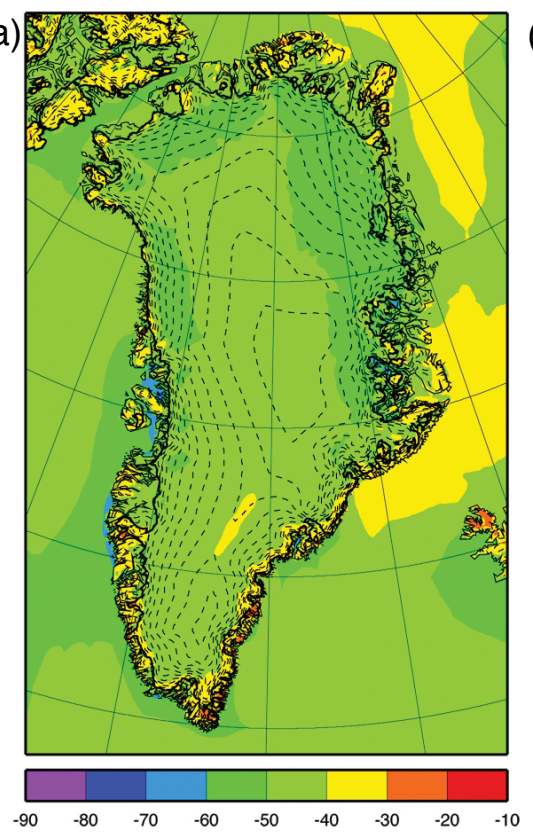

(b)

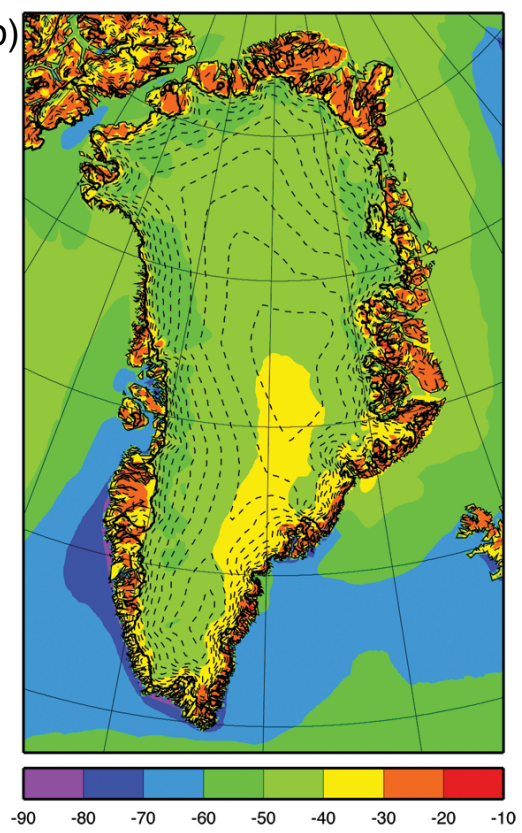

(c)

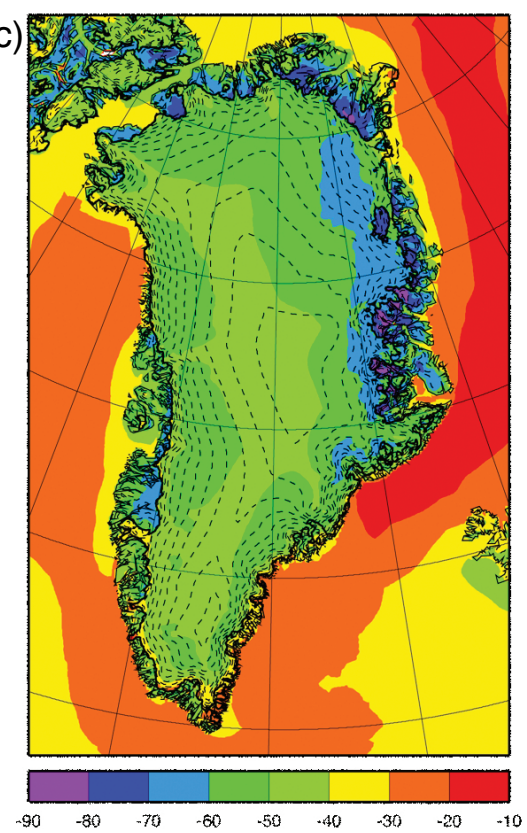

Fig. 10. Averaged net longwave radiation $\left[\mathrm{W} \mathrm{m}^{-2}\right]$ over (a) a year, and the seasons (b) DJF and (c) JJA.

(a)

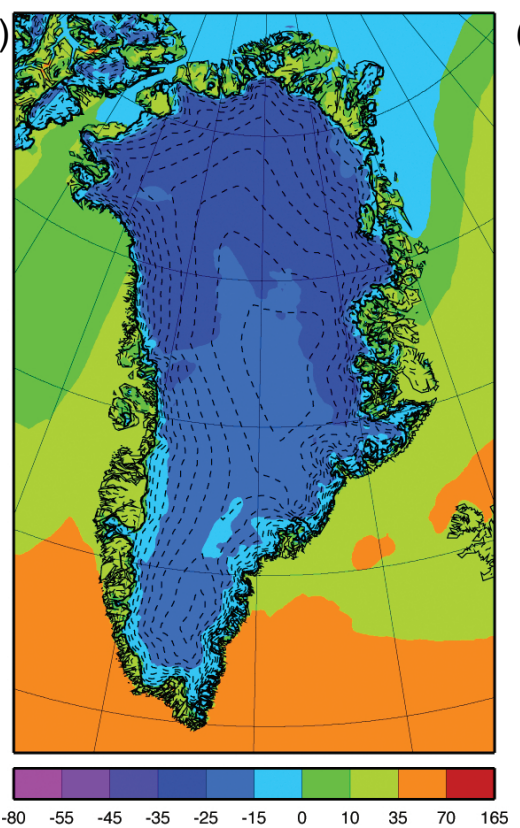

(b)

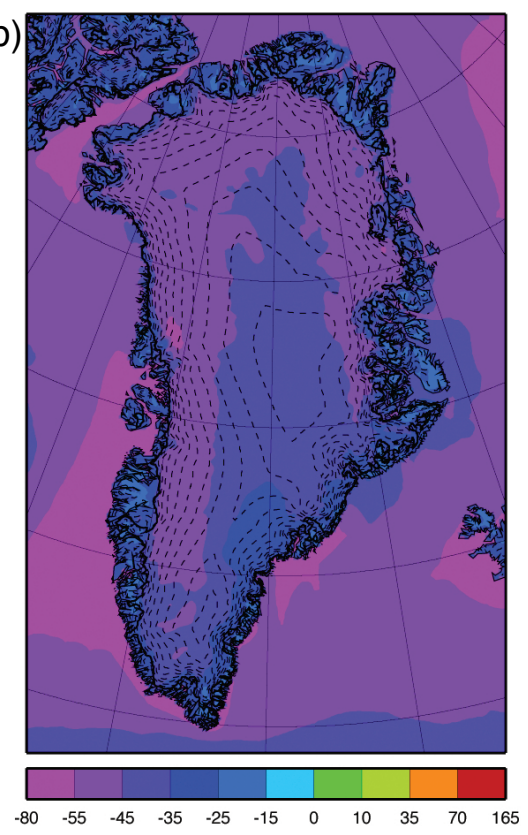

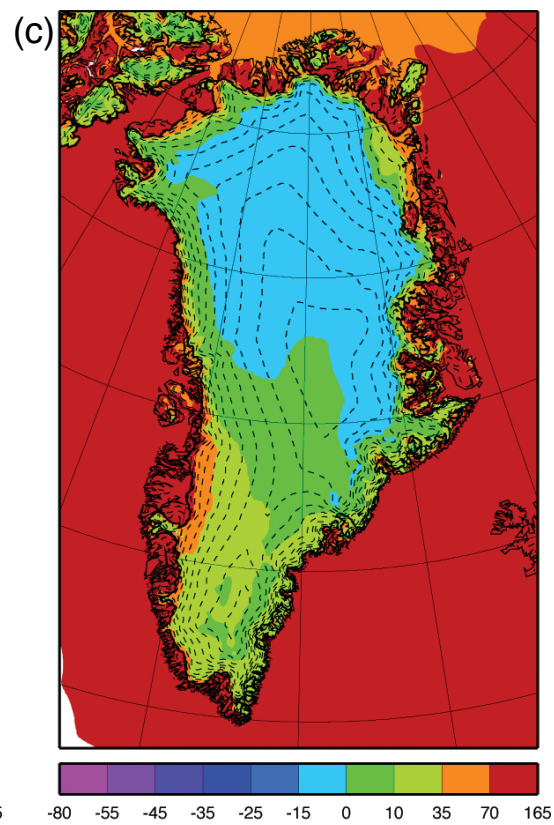

Fig. 11. Averaged net surface radiation $\left[\mathrm{W} \mathrm{m}^{-2}\right]$ ) over (a) a year, and the seasons (b) DJF and (c) JJA.

Downwelling infrared radiation at the surface $\mathrm{LW}_{\downarrow}$ is a function of the temperature and humidity distribution in the lowest atmospheric layers, but also of low level clouds, which determine the atmospheric longwave radiative properties. Therefore, $\mathrm{LW}_{\downarrow}$ (not shown) shows large similarities (albeit reversed) with the SW transmissivity. The emitted $\mathrm{LW}$ radiation $\mathrm{LW}_{\uparrow}$ is mainly $(\epsilon \sim 1)$ determined by the surface temperature, leading to annual mean simulated net emit- ted longwave radiation $\mathrm{LW}_{\text {net }}$ between -30 and $-60 \mathrm{~W} \mathrm{~m}^{-2}$ (Fig. 10a). As seen in Fig. 10, $\mathrm{LW}_{\text {net }}$ is rather constant throughout the year, between -60 and $-40 \mathrm{~W} \mathrm{~m}^{-2}$, except for the northeast, where in summer values of $-65 \mathrm{Wm}^{-2}$ (Fig. 10c) are found due to less $\mathrm{LW}_{\downarrow}$. RACMO2/GR is known to underestimate $\mathrm{LW}_{\downarrow}$ during the winter months (Ettema et al., 2010; Van de Berg et al., 2008). Therefore, the modelled DJF LW $W_{\text {net }}$ (Fig. 10b) values are likely too low. 
The negative $\mathrm{LW}_{\text {net }}$, and the associated cooling of the surface, indirectly forces the katabatic circulation over Greenland, which prevents or reduces cloud cover and contributes to the development of the Greenland shallow high pressure system. In general, the heat loss due to LW emission increases towards lower elevations, with maximum values in Dronning Louise Land (Fig. 10a). The characteristics for this area are the very strong katabatic winds that bring cold, dry air from the interior, and the absence of large scale advection of moist air, both reducing the moisture content of the overlying air and, thus, $\mathrm{LW}_{\downarrow}$. Moreover, the katabatic winds effectively heat the surface through SHF, increasing $T_{\mathrm{S}}$ and $\mathrm{LW}_{\uparrow}$ and enhancing the radiative heat loss.

In the western lower ablation zone, $\mathrm{LW}_{\text {net }}$ decreases again with altitude. Here, the emission of LW radiation is limited in summer due to continuous melting at the surface, which causes a smaller LW radiative heat loss than for areas where the melting is intermittent during the melt season (Van den Broeke et al., 2008a).

\subsubsection{Net radiation}

The sum of $\mathrm{SW}_{\text {net }}$ and $\mathrm{LW}_{\text {net }}$ equals the net radiation (Fig. 11). The annual mean net radiation is, on average, negative everywhere on the ice sheet, implying that on an annual basis the heat loss by $\mathrm{LW}_{\text {net }}$ is larger than the absorption of shortwave radiation. This heat loss decreases sharply to zero close to the ice sheet margin, where the relatively smaller heat loss due to LW is compensated by the increased SW absorption due to the low albedo. Observations by Van den Broeke et al. (2008a) confirm that small positive values of annual mean net radiation can occur at $6 \mathrm{~km}$ from the ice margin, while small negative values are observed in the higher ablation and percolation zone, which is in good agreement with Fig. 11a. The net radiative cooling has to be compensated by the subsurface heat flux and, in particular, turbulent heat fluxes.

In winter, the net radiation is dominated by $\mathrm{LW}_{\text {net }}$ in $\mathrm{ab}$ sence of sunlight (Fig. 11b). In summer, $\mathrm{SW}_{\text {net }}$ exceeds $\mathrm{LW}_{\text {net }}$, especially along the margins where the net radiation flux reaches up to $75 \mathrm{~W} \mathrm{~m}^{-2}$ (Fig. 11c). Only the northern part of the interior is exposed to small negative net radiation fluxes $\left(-6 \mathrm{~W} \mathrm{~m}^{-2}\right)$, which will be compensated by turbulent heat fluxes.

\subsubsection{Turbulent fluxes of sensible and latent heat}

The turbulent scales of momentum $u_{*}$, moisture $q_{*}$ and heat $\theta_{*}$ are computed to provide insight into the relative contributions of the wind, humidity and temperature near-surface gradients to the surface latent and sensible heat fluxes, SHF and LHF (Eq. 9). The spatial distribution of $\theta_{*}$ (Fig. 12a) shows similarities (albeit reversed) with potential temperature (Fig. 5a) and surface temperature deficit (Fig. 6b). Positive/negative $\theta_{*}$ means that the surface layer is, on average, stably/unstably stratified. The radiative cooling of the surface enforces positive $\theta_{*}$ values and a stable atmospheric boundary layer over the ice sheet interior. Negative $\theta_{*}$ values are found over the ocean, where convection occurs when cold air is transported over the warm ocean water.

Figure $12 \mathrm{~b}$ shows that annual mean $q_{*}$ decreases and becomes negative towards the ice sheet margins, signifying sublimation/evaporation. In the dry snow zone, $q_{*}$ remains positive throughout the year, an indication for net deposition. Below 2000 m elevation, the surface-to-air specific humidity gradient is very small in winter in response to the low temperatures. In spring and summer, the surface is heated, but not yet melting, leading to strongly negative values for $q_{*}$ implying sublimation. Here, the magnitude of $q_{*}$ is much larger in summer than in winter resulting in negative values on an annual basis.

The spatial distribution of $u_{*}$ (Fig. 12c) qualitatively follows the $10 \mathrm{~m}$ wind speed (Fig. 2a). The increasing surface roughness towards the margins enhances $u_{*}$. These high values along the margins are necessary to maintain mechanical generation of turbulence in the stably stratified boundary layer (Van den Broeke et al., 2008c).

In the ice sheet interior, the relatively large values of $\theta_{*}$ coincide with low friction velocities, leading to a rather homogeneous distribution of annual mean $\operatorname{SHF}\left(\sim u_{*} \theta_{*}\right)$ as seen in Fig. 13a. The positive SHF values indicate cooling of the atmospheric boundary layer and heating of the surface. The annual SHF increases towards the margins to maximum values of $+38 \mathrm{~W} \mathrm{~m}^{-2}$ at about $50 \mathrm{~km}$ from the ice edge, except for the southeastern part of the ice sheet. This enhancement can be ascribed mostly to the positive coupling between $u_{*}$ and $\theta_{*}$. Strong radiative cooling leads to large $\theta_{*}$, which through katabatic forcing enhances $u_{*}$, leading to large values of SHF as long as the radiative cooling is maintained. As a result, SHF is largest in winter (Fig. 13b) and smallest in summer (Fig. 13c).

The decreasing SHF at the ice edge is the result of the deceleration of the katabatic winds, as found in the northern and western parts of Greenland. Over the ice sheet, SHF almost fully compensates the radiative heat loss. Over the surrounding oceans, negative values for SHF are found, because on average cold air flows over a relatively warm sea surface. An exception is the area with seasonal sea ice cover, which insulates the warm ocean from the atmosphere and experiences net warming by SHF.

Over the ice sheet, the magnitude of LHF $\left(\sim u_{*} q_{*}\right)$ is much smaller than SHF, both annually and seasonally (Fig. 14). On an annual basis, deposition (LHF $>0$ ) dominates in the interior of the GrIS, while sublimation $(\mathrm{LHF}<0)$ prevails in the ablation and percolation zones. This pattern can be ascribed to $q_{*}$. Deposition occurs at elevations over $2000 \mathrm{~m}$ throughout the year (Fig. 14b and c) and is associated with the strong surface temperature inversions due to radiative cooling. Relatively strong sublimation $\left(-12 \mathrm{~W} \mathrm{~m}^{-2}\right)$ 
(a)

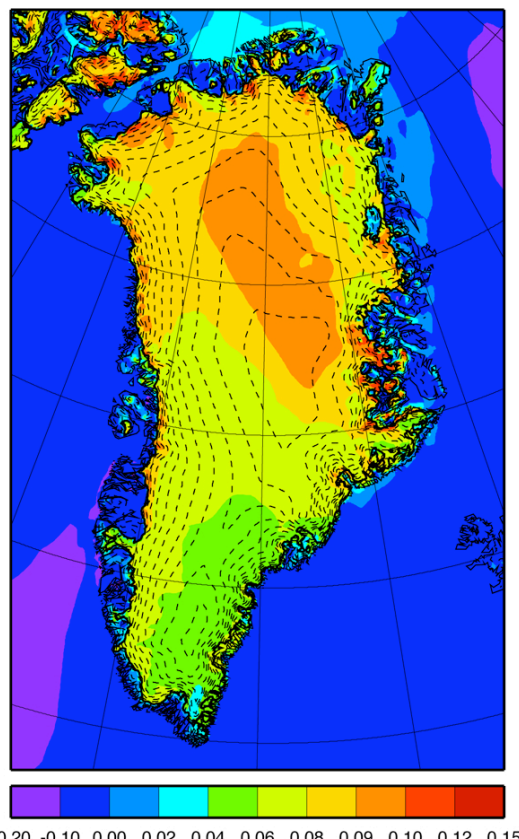

(b)

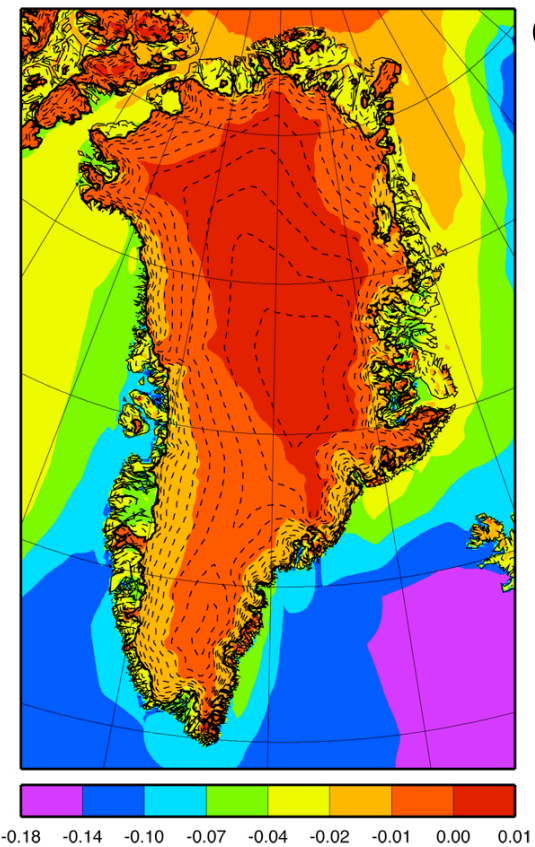

(c)
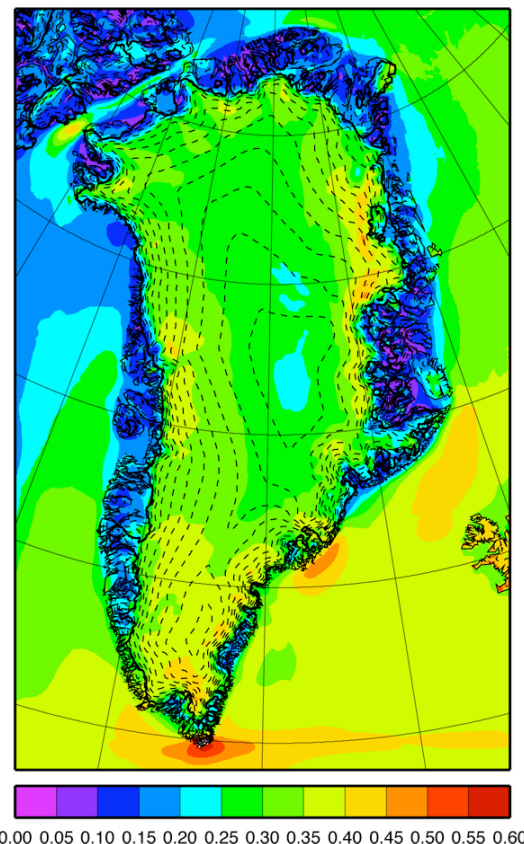

Fig. 12. Annual mean (a) turbulent temperature scale $\theta_{*}[\mathrm{~K}]$, (b) turbulent humidity scale $q_{*}\left[\mathrm{~g} \mathrm{~kg}^{-1}\right]$, and (c) friction velocity $u_{*}\left[\mathrm{~m} \mathrm{~s}^{-1}\right]$ over the period 1958-2008.

(a)

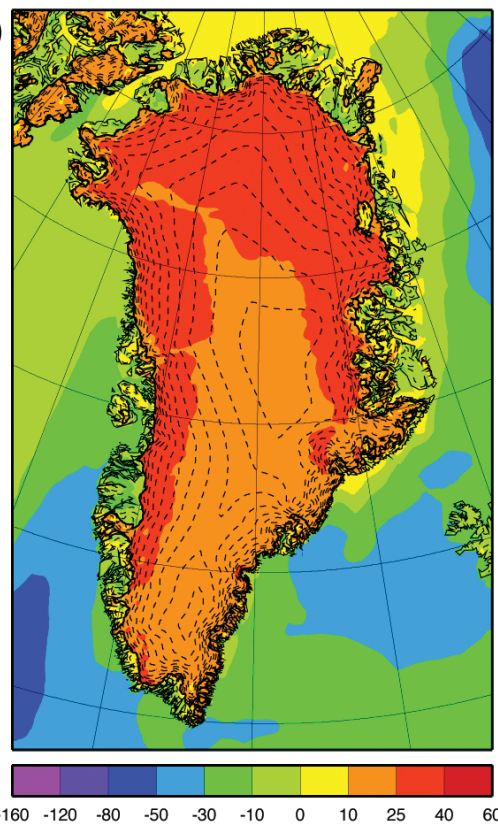

(b)

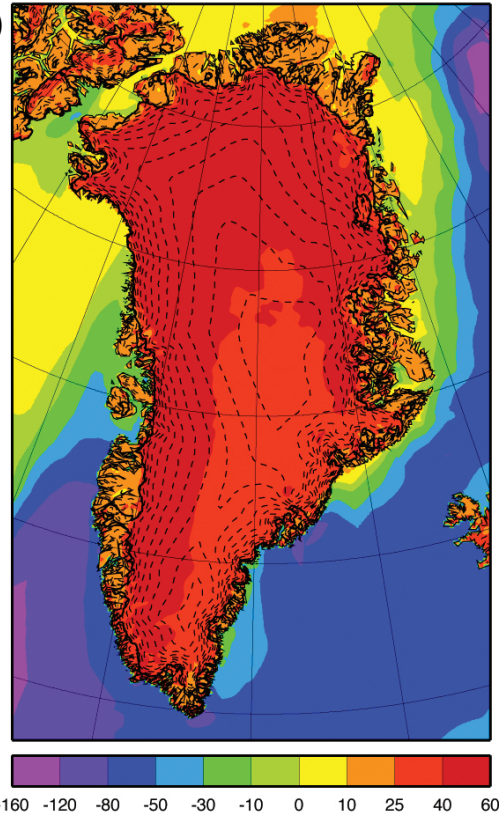

(c)

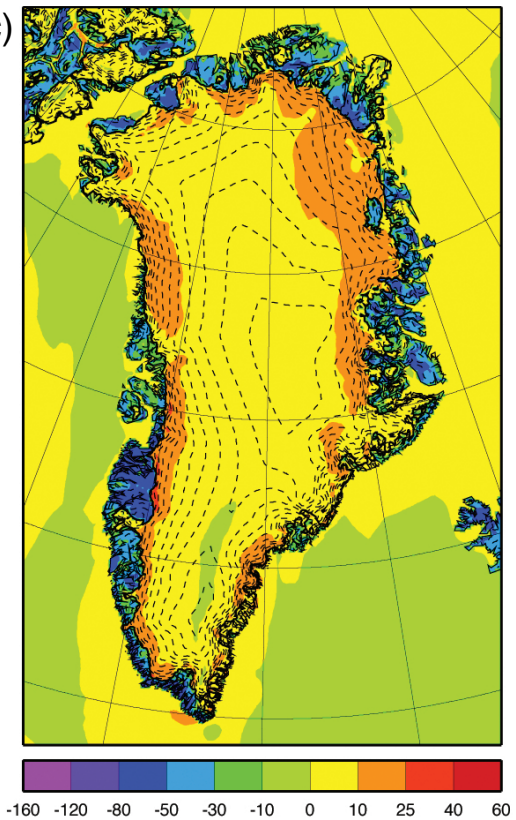

Fig. 13. Averaged turbulent sensible heat flux SHF $\left[\mathrm{W} \mathrm{m}^{-2}\right]$ ) over (a) a year, and the seasons (b) DJF and (c) JJA.

occurs in spring and summer on locations where the snow surface is heated but does not yet melt.

The modelled LHF agrees well with the sublimation map based on GC-net observations along or above the equilibrium line altitude (Box and Steffen, 2001), except for the southwestern lower ablation zone where the modelled LHF decreases close to the ice edge. Here, sublimation changes regularly into deposition in summer as a result of fixed $T_{\mathrm{S}}$ during melt. These summer reversals occur less frequently with increasing elevation, and here sublimation dominates in summer. This model result agrees with AWS observations in the southwestern ablation zone described by Van den Broeke 
(a)

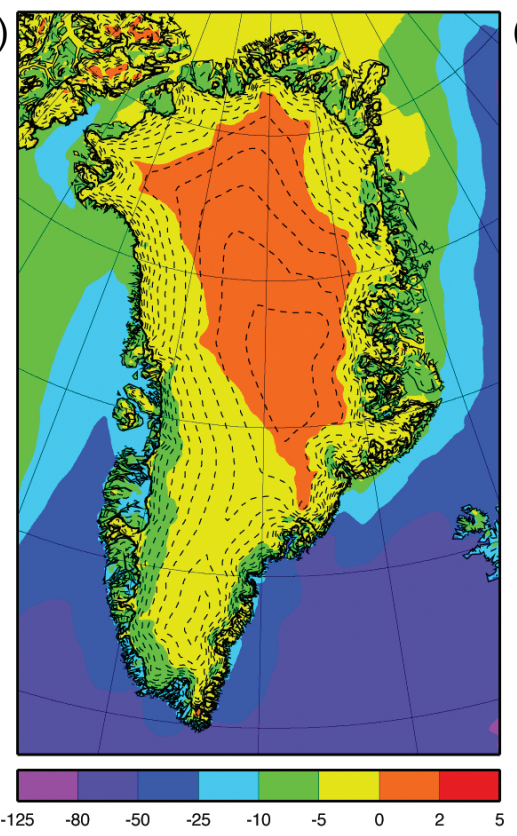

(b)

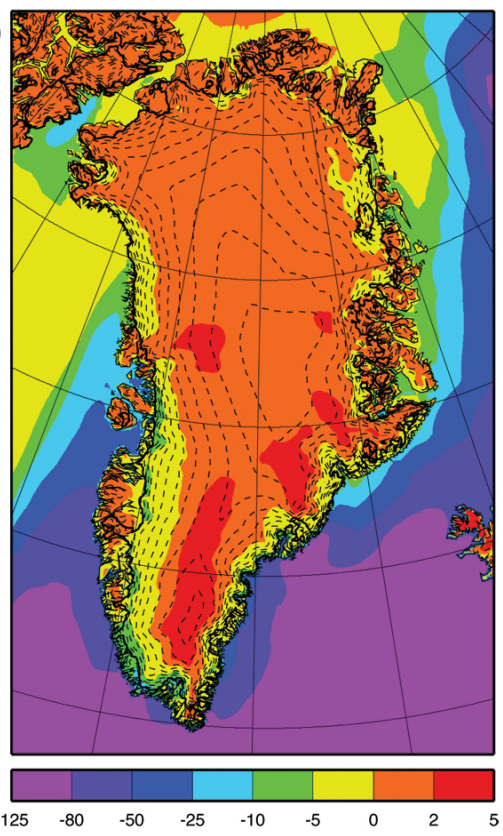

(c)

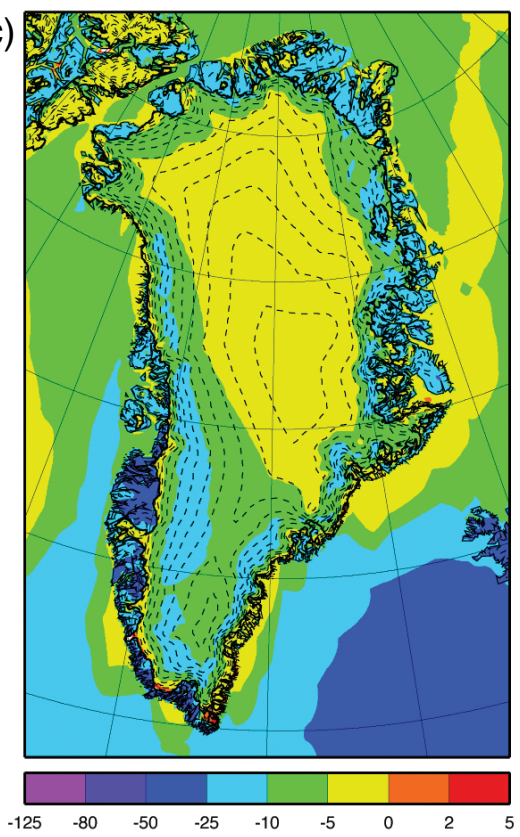

Fig. 14. Averaged turbulent latent heat flux LHF $\left[\mathrm{W} \mathrm{m}^{-2}\right]$ ) over (a) a year, and the seasons (b) DJF and (c) JJA.

(a)

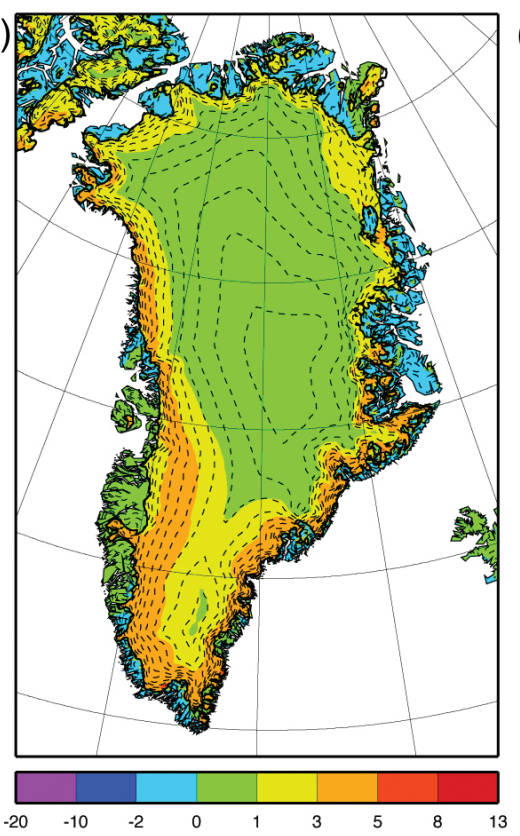

(b)

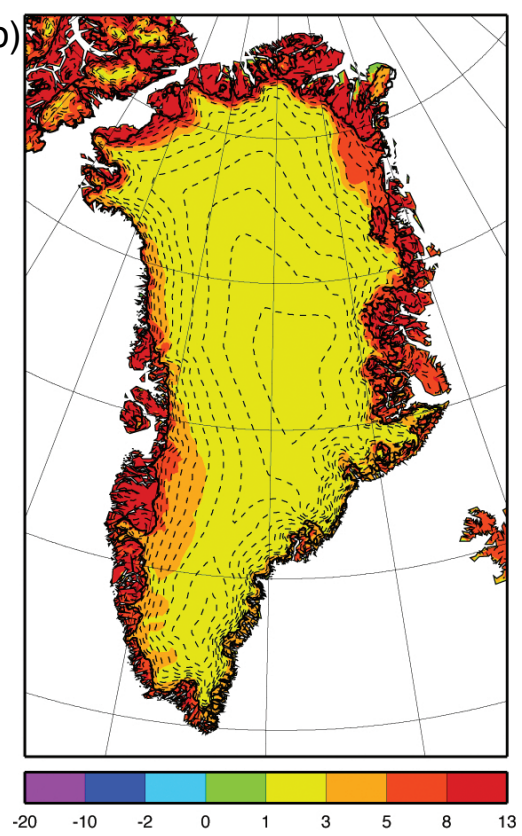

(c)

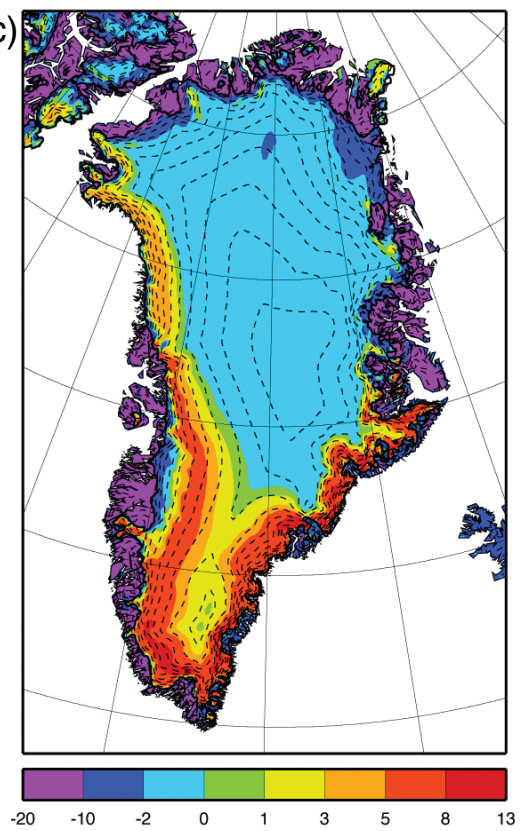

Fig. 15. Averaged subsurface heat flux $G_{\mathrm{S}}\left[\mathrm{W} \mathrm{m}^{-2}\right]$ over (a) a year, and the seasons (b) DJF and (c) JJA.

et al. (2008c). The summertime sublimation $\left(\sim-10 \mathrm{~W} \mathrm{~m}^{-2}\right.$ for July) in the percolation zone absorbs part of the energy that would otherwise be available for melting. This implies that despite its relatively small magnitude, LHF plays an important role in maintaining the ice sheet, as was already suggested by Henneken et al. (1994).

\subsubsection{Melt energy and subsurface heat flux}

Figures 15a and 16 show the 1958-2008 maps for the annual mean subsurface heat flux, $G_{\mathrm{s}}$ and melt energy, $M$. Both depict similar patterns over the ice sheet, nevertheless $M$ is a magnitude larger than $G_{\mathrm{s}}$. The heat gain from the lower snow/ice layers towards the surface increases from near zero in the dry snow zone to $+4.5 \mathrm{~W} \mathrm{~m}^{-2}$ at the margins. In the 


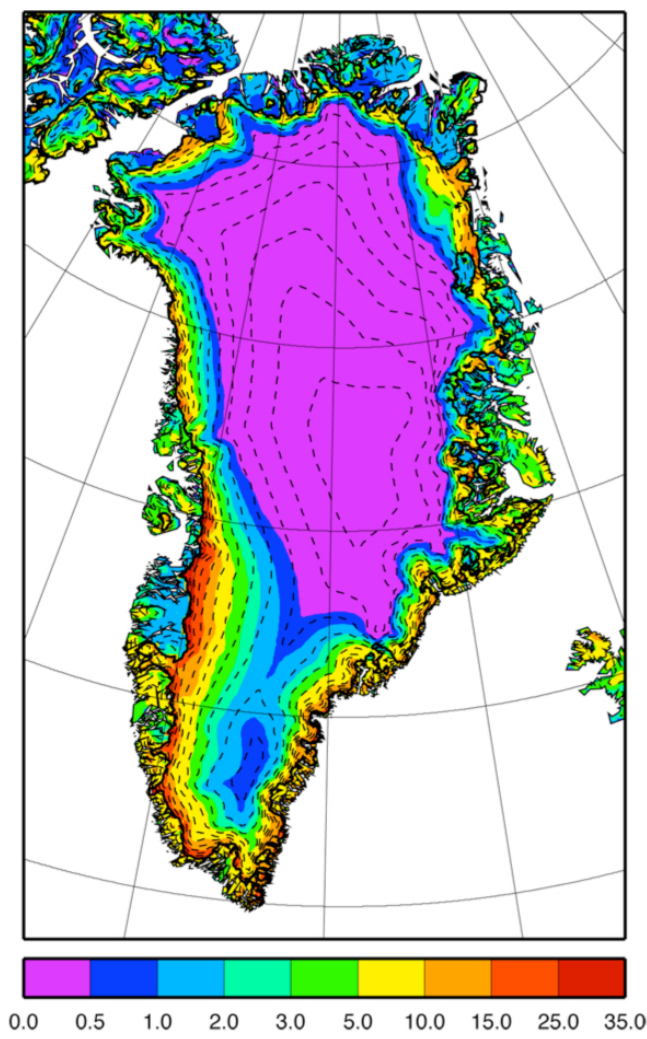

Fig. 16. Annual mean melt energy $M\left[\mathrm{~W} \mathrm{~m}^{-2}\right]$.

percolation zone, $G_{\mathrm{s}}$ is mostly positive during summer, because of the heat release in the snow pack due to refreezing of melt water (Fig. 15c). Closer to the ice edge in western Greenland, the mean $G_{\mathrm{s}}$ is found to slightly decrease. In these areas, $G_{\mathrm{s}}$ is small in summer, because the upper ice layers become isothermal due to the continuous melting. This feature is confirmed by measurements along the K-transect (Van den Broeke et al., 2008b). In winter, the surface is colder than the underlying snow everywhere, resulting in a positive $G_{\mathrm{s}}$ with the highest values $\left(5 \mathrm{~W} \mathrm{~m}^{-2}\right)$ along the margins (Fig. 15b). Only in areas without significant summer melt, is the annual mean of $G_{\mathrm{s}}$ close to zero.

There is an obvious correlation between the amount of melt $M$ and the surface albedo $\alpha$ (Fig. 8a). Low values of $\alpha$ coincide with a large $M$, because a darker surface absorbs more shortwave radiation, which becomes available for melting once the surface temperature is at the melting point. In turn, this melting lowers $\alpha$ further until the bare glacier ice is at the surface, inducing the onset of a positive feedback that lasts until the first snowfall event increases the albedo. Konzelmann and Braithwaite (1995) found the same correlation based on observations of the daily ablation and the estimated albedo at ETH Camp in the western ablation zone.

\section{Summary and conclusions}

A 51-year simulation (1958-2008) of the climate of the GrIS and its immediate surroundings has been performed with the regional atmospheric climate model RACMO2/GR at 11-km resolution, driven by ERA-40 and ECMWF operational analyses at the lateral boundaries and sea surface. The model output is evaluated in Part 1 of this paper. Here, a detailed analysis of the model simulated near-surface climate (temperature, wind, humidity, atmospheric and surface properties, and SEB) averaged over this period is presented.

The comparison of the simulated annual mean air temperature with the temperature parameterization of Reeh (1991) reveals that elevation and latitude determine largely the spatial distribution of the near-surface temperature over the ice sheet. Including the dependency on longitude in the empirical function and using a more recent observational dataset for coefficient optimalization as done by Fausto et al. (2009), improves the agreement between the modelled and parameterized temperature fields. Compared to the model output, both functions show large negative temperature biases along the eastern lower margins, where the largest wind speeds and lowest relative humidities are modelled. For these elevations, both parameterizations are apparently too simple, because other factors such as large scale heat/cold advection, mesoscale topography and the occurrence of summer melt appear to affect the local temperature.

The surface potential temperature deficit is quasipermanent over the whole ice sheet and is caused by quasicontinuous net radiative cooling. Due to strong vertical mixing by the katabatic winds, the SHF is large enough to balance most of the radiative heat loss. The positive subsurface heat flux compensates for the remaining energy shortage at the surface. As a result, the atmospheric boundary layer cools continuously and the cold air flows away from the interior of the ice sheet as persistent katabatic winds that are directed towards the ice sheet margins.

Near the top of the ice sheet, in absence of katabatic forcing the large scale pressure gradient force is the dominant factor controlling the near-surface wind field. Here, the outflow of air is compensated by subsidence of potentially warmer air from the free atmosphere, reducing the vertically integrated temperature perturbation. The modelled high cloud coverage over the interior frequently only consists of a shallow fog layer as the $\mathrm{SW}$ transmissivity is rather high $\left(\mathrm{SW}_{\downarrow} / \mathrm{SW}_{\downarrow}, \mathrm{TOA}>0.65\right)$.

In summer, the katabatic wind system is much weaker due to a smaller surface temperature deficit. For large parts of the ice sheet, the net radiation becomes positive due to enhanced shortwave radiation absorption by the darker surface that results from snow metamorphism. As the summer nearsurface temperature gradient remains positive, the net radiative warming of the surface is not compensated by the SHF, but rather enhanced. As soon as the snow/firn/ice surface reaches the melting point, the remaining energy at the sur- 
face is available for melt. In the percolation zone, the subsurface heat flux is an additional significant contributor of energy to the surface as the meltwater in the snowpack refreezes overnight.

With respect to spatial variability, the northeastern part of the ice sheet stands out. The RACMO2/GR output shows that close to the margin, the largest mean wind speeds and smallest values for relative humidity can be found. The annual mean longwave radiative cooling is largely due to a clear sky (lowest cloud cover and highest SW transmissivity). Moreover, the concave surface and a synoptic pressure gradient favourable for advection of cold air keep the air cold, further enhancing the katabatic forcing. As subsidence of warmer air from the free atmosphere is suppressed, the strongest temperature deficit occurs over the northeastern part of the ice sheet.

Apart from the insight into the near surface climate and the surface energy balance over the Greenland ice sheet, highresolution regional climate models can be used for further exploration of the atmospheric heat and momentum budgets, as well as the temporal variability of the atmospheric boundary layer characteristics. Additionally, it would be interesting to understand the recent changes in the near-surface climate and SEB, including the climatological extremes, over Greenland with respect to global warming. These topics will be addressed in future articles.

Acknowledgements. This work is funded by the RAPID international programme (Netherlands, UK, Norway), Utrecht University, the Netherlands Polar Program of NWO/ALW. The ECMWF and KNMI are thanked for providing computing and data archiving support.

Edited by: J. L. Bamber

\section{References}

Ambach, W.: Untersuchungen zum Energieumsatz in der Ablationszone des Grönländischen Inlandeises, Expedition Glaciologique Internationale au Groenland, 4, 63, Bianco Lunos Bogtrykkeri A/S, Kopenhagen, 1977a.

Ambach, W.: Untersuchungen zum Energieumsatz in der Akkumulationszone des Grönländischen Inlandeises, Expedition Glaciologique Internationale au Groenland, 4, 44, Bianco Lunos Bogtrykkeri A/S, Kopenhagen, 1977b.

Box, J. E. and Steffen, K.: Sublimation on the Greenland ice sheet from automated weather station observations, J. Geophys. Res., 106, 33965-33981, 2001.

Bromwich, D. H.: An extraordinary katabatic wind regime at Terra Nova Bay, Antarctica, Mon. Weather Rev., 117, 688-695, 1989.

Cassano, J. J., Box, J. E., Bromwich, D. H., Li, L., and Steffen, K.: Evaluation of Polar MM5 simulations of Greenland's atmospheric circulation, J. Geophys. Res., 106, 33867-33889, 2001.

Chen, Q.-S., Bromwich, D. H., and Bai, L.: Precipitation over Greenland retrieved by a dynamic method and its relation to cyclonic activity, J. Climate, 10, 839-870, 1997.

Dethloff, K., Schware, M., Christensen, J. H., Kiilsholm, S., Rinke, A., Fischer, H., Kipfstuhl, S., and Miller, H.: Recent Greenland accumulation estimated from regional climate model simulations and ice core analysis, J. Climate, 15, 2821-2832, 2002.

Duynkerke, P. G. and van den Broeke, M. R.: Surface energy balance and katabatic flow over glacier and tundra GIMEX-91, Global Planet. Change, 9, 17-28, 1994.

Dyer, A. J.: A review of flux-profile relationships, Bound.-Lay. Meteorol., 7, 363-372, 1974.

Ettema, J., van den Broeke, M. R., van Meijgaard, E., van de Berg, W. J., Bamber, J. L., Box, J. E., and Bales, R. C.: Higher surface mass balance of the Greenland ice sheet revealed by highresolution climate modeling, Geophys. Res. Lett., 36, L12501, doi:10.1029/2009GL038110, 2009.

Ettema, J., van den Broeke, M. R., van Meijgaard, E., van de Berg, W. J., Box, J. E., and Steffen, K.: Climate of the Greenland ice sheet using a high-resolution climate model, Part 1: Evaluation, The Cryosphere, 4, 511-527, doi:10.5194/tc-4-511-2010, 2010.

Fausto, R. S., Ahlstrom, A. P., van As, D., Bøggild, C. E., and Johnsen, S. J.: A new present-day temperature parameteruzation for Greenland, J. Glaciol., 55, 95-105, 2009.

Fettweis, X.: Reconstruction of the 1979-2006 Greenland ice sheet surface mass balance using the regional climate model MAR, The Cryosphere, 1, 21-40, doi:10.5194/tc-1-21-2007, 2007.

Gallée, H. and Pettré, P.: Dynamical constraints on katabatic wind cessation in Adélie Land, Antarctica, J. Atmos. Sci., 55, 17551770, 1998.

Hanna, E., Huybrechts, P., Steffen, K., Cappelen, J., Huff, R., Shuman, C., Irvine-Fynn, T., Wise, S., and Griffiths, M.: Increased runoff from melting from the Greenland ice sheet: a response to global warming, J. Climate, 21, 331-341, doi:10.1175/ 2007JCLI1964.1, 2008.

Heinemann, G.: The KABEG'97 field experiment: an aircraftbased study of katabatic wind dynamics over the Greenland ice sheet, Bound.-Lay. Meteorol., 93, 75-116, doi:10.1023/A: $1002009530877,1999$.

Henneken, E. A. C., Bink, N. J., Vugts, H. F., Cannemeijer, F., and Meesters, A. G. C. A.: A case study of the daily energy balance near the equilibrium line on the Greenland ice sheet, Global Planet. Change, 9, 69-78, 1994.

Hines, K. M. and Bromwich, D. H.: Development and testing of polar weather research and forecasting (WRF) model. Part I: Greenland ice sheet meteorology, Mon. Weather Rev., 136, 1971-1989, doi:10.1175/2007MWR21112.1, 2008.

Hoch, S.: Radiative flux divergence in the surface boundary layer, a study based on observations at Summit. Greenland, Ph.D. thesis, Swiss Federal Institute of Technology (ETH) Zurich, 180 pp., 2005.

Hoch, S. W., Calanca, P., Philipona, R., and Ohmura, A.: Yearround observation of longwave radiative flux divergence in Greenland, J. Appl. Meteorol., 46, 1469-1479, doi:10.1175/ JAM2542.1, 2007.

Holtslag, A. A. M. and Bruin, H. A. R. D.: Applied modelling of the night-time surface energy balance over land, J. Appl. Meteorol., 27, 689-704, 1988.

Konzelmann, T. and Braithwaite, R. J.: Variation of ablation, albedo and energy balance at the margin of the Greenland ice sheet, Kronprins Christian Land, eastern north Greenland, J. Glaciol., 41, 174-182, 1995.

Moore, G. W. K. and Renfrew, I. A.: Tip jet and barrier winds: a Quickscat climatology of high wind speed events around Green- 
land, J. Climate, 18, 3713-3725, 2005.

Oerlemans, J. and Vugts, H. F.: A Meteorological experiment in the melting zone of the Greenland ice sheet, B. Am. Meteorol. Soc., 74, 3-26, 1993.

Ohmura, A.: New temperature distribution maps for Greenland, Z. Gletscherkd. Glazialgeol., 23, 1-45, 1987.

Ohmura, A. and Reeh, N.: New precipitation and accumulation maps for Greenland, J. Glaciol., 37, 140-148, 1991.

Reeh, N.: Parameterization of melt rate and surface temperature on the Greenland ice sheet, Polarforschung, 59(3), 113-128, 1991.

Scorer, R. S.: Sunny Greenland, Q. J. Roy. Meteorol. Soc., 114, 3-29, 1988.

Steffen, K. and Box, J. E.: Surface climatology of the Greenland Ice sheet: Greenland Climate Network 1995-1999, J. Geophys. Res., 106, 33951-33964, 2001.

Tsukernik, M., Kindig, D. N., and Serreze, M. C.: Characteristics of winter cyclone activiy in the northern North Atlantic: insights from observations and regional modelling, J. Geophys. Res., 112, D03101, doi:10.1029/2006JD007174, 2007.

Undén, P., Rontu, L., Järvinen, H., Lynch, P., Calvo, J., Cats, G., Cuxart, J., Eerola, K., Fortelius, C., Garcia-Moya, J. A., Jones, C., Lenderink, G., McDonald, A., McGrath, R., Navascues, B., Woetman Nielsen, N., Ødegaard, V., Rodriguez, E., Rummukainen, M., Rõõm, R., Sattler, K., Sass, B. H., Savijärvi, H., Schreur, B. W., Sigg, R., The, H., and Tijm, A.: High Resolution Limited Area Model, HIRLAM-5 scientific documentation, Tech. rep., Swed. Meteorol. and Hydrol. Inst, Norrköping, Sweden, 144 pp., 2002.

Van de Berg, W. J., van den Broeke, M. R., Reijmer, C. H., and van Meijgaard, E.: Characteristics of the Antarctic Surface Mass Balance (1958-2002) Using a Regional Atmospheric Climate Model, Ann. Glaciol., 41, 97-104, 2005.

van de Berg, W. J., van den Broeke, M. R., and van Meijgaard, E.: Spatial structures in the heat budget of the Antarctic atmospheric boundary layer, The Cryosphere, 2, 1-12, doi:10.5194/tc-2-12008, 2008.
Van den Broeke, M., Smeets, P., Ettema, J., and Kuipers Munnike, P.: Surface radiation balance in the ablation zone of the west Greenland ice sheet, J. Geophys. Res., 113, D13105, doi:10. 1029/2007JD009283, 2008a.

van den Broeke, M., Smeets, P., Ettema, J., van der Veen, C., van de Wal, R., and Oerlemans, J.: Partitioning of melt energy and meltwater fluxes in the ablation zone of the west Greenland ice sheet, The Cryosphere, 2, 179-189, doi:10.5194/tc-2-179-2008, 2008b.

Van den Broeke, M. R. and van Lipzig, N. P. M.: Factors controlling the near-surface wind field in Antarctica, Mon. Weather Rev., 131, 733-743, 2003.

Van den Broeke, M. R., Duynkerke, P. G., and Oerlemans, J.: The observed katabatic flow at the edge of the Greenland ice sheet during GIMEX-91, Global Planet. Change, 9, 3-15, 1994.

Van den Broeke, M. R., van Lipzig, N. P. M., and Van Meijgaard, E.: Momentum budget of the East Antarctic atmospheric boundery layer: results of a regional climate model, J. Atmos. Sci., 59, 3117-3129, 2002.

Van den Broeke, M. R., Smeets, P., and Ettema, J.: Surface layer climate and turbulent exchange in the ablation zone of the west Greenland ice sheet, Int. J. Climatol., 2309-2323, doi:10.1002/ joc. $1815,2008 \mathrm{c}$.

Van Meijgaard, E., van Ulft, L. H., van de Berg, W. J., Bosveld, F. C., van den Hurk, B. J. J. M., Lenderink, G., and Siebesma, A. P.: The KNMI regional atmospheric climate model RACMO version 2.1, Tech. Rep. 302, KNMI, De Bilt, The Netherlands, 2008.

White, P. W. (Ed.): IFS documentation CY23r4: Part IV physical processes, available at: http://www.ecmwf.int/research/ifsdocs/, 2004. 